\title{
VALDIS TËRAUDKALNS
}

\section{CERĪBU LAIKS: LELB KONTAKTI AR ANGLIJAS BAZNĪCU ARHIBITSKAPA GUSTAVA TŪRA DARBĪBAS LAIKĀ $(1946-1968)^{1}$}

Šī raksta mērķis ir aplūkot Latvijas Evaņgēeliski luteriskās baznīcas (LELB) attiecības ar Anglijas (anglikāṇu) baznīcu LELB arhibīskapa Gustava Tūra darbības laikā, "ieliekot" šos kontaktus dažādos - teoloǵiskos, sociāli politiskos, personību savstarpējo attiecību - kontekstos. Runājot par vēsturi, protams, jāpatur prātā, ka avoti ir logi uz pagātni un nevis uzticami pavadoṇi vēstures izpētē. Tāpēc pētījumā salīdzināta arhīvos, intervijās, publikācijās iegūtā informācija, l̦aujot šiem avotiem "sarunāties" savā starpā, konfrontēt vienam otru. Rakstā izmantoti arī līdz šim pētniecībā Latvijā neizmantoti avoti, kas atrodami Lambetas pils bibliotēkas arhīvā Londonā. Raksts turpina citu pētnieku sākto - reliğisko organizāciju darbību un to attiecības ar valsti aplūkotajā

1 Raksts izstrādāts Valsts pētījumu programmas "Latvijas mantojums un nākotnes izaicinājumi valsts ilgtspējai" projektā "Indivīda, sabiedrības un valsts mijiedarbība kopējā Latvijas vēstures procesā: vērtību konflikti un kopīgu vērtību veidošanās vēsturiskos lūzumu punktos" (VPP-IZM-2018/1-0018).

1946. gadā G. Tūrs sāka darboties kā arhibīskapa vietas izpildītājs, 1968. gadā viņš amatu atstāja. 
laika posmā pētījuši Solveiga Krūmiña-Koṇkova, ${ }^{2}$ Zanda Mankusa, ${ }^{3}$ Linards Rozentāls, ${ }^{4}$ Jouko Talonens ${ }^{5}$ u. c.

Abu baznīcu sakariem pēc Otrā pasaules kara ir priekšvēsture, kas saistìta gan ar anglikāņu interesi par ekumenismu, gan ar luterānu garīdzniecības daḷas centieniem iziet plašākā ekumeniskā "arēnā", atbrīvojoties no līdzšinējās ciešās saistības ar vācu luterismu. Kā, komentējot anglikāņu delegācijas vizīti Rīgā 1938. gadā, rakstīja latviešu teologs Edgars Rumba, "evanggeêliskie latvieši, atraisījušies no svešas aizbildniecības, atrodas ceḷā uz patstāvīgu baznīcas dzīvi”. Partnerība ar Skandināvijas luterāñiem un anglikāņiem šajā ceḷā likās cerīga. 1936. un 1938. gada sarunas starp Igaunijas un Latvijas luterāņu baznīcu un Anglijas baznīcas pārstāvjiem rezultējās deklarācijas tekstā, kura pamatā bija vienošanās ar Somijas baznīcu (1934. g.). Tajā paredzēts, ka anglikāņu un luterāņu bīskapi piedalītos jauna minēto baznīcu bīskapa konsekrācijā un arī bīskapu sanāksmēs, vienas konfesijas draudžu locekḷı drīkstētu iet pie dievgalda otras konfesijas baznīcā, tas pats attiektos uz laulāšanu un kristǐšanu. ${ }^{7}$

Padomju okupācija apstādināja uzsākto sadraudzības procesu. Pēc Otrā pasaules kara Latvijas baznīcu kontakti ar ārzemēm gan lēnām atjaunojās, taču stingrā valsts kontrolē. 1946. gada jūlijā Rīgu apmeklēja Lielbritānijas-PSRS asociācijas delegācija, kuru vadijja Stenlijs Evanss (Evans), politiski kreisi orientēts anglikāņu mācītājs. ${ }^{8}$ Vēlāk, 1953. gadā, viņš sadusmoja Vinstonu Čērčilu, vadot delegāciju, kura pēdējās stundās

2 Solveiga Krūmiņa-Koṇkova, "Sadarbība starp LPSR drošības iestādēm un PSRS Reliǵisko kultu lietu padomes pilnvaroto LPSR (1944-1954)", VDK Zinātniskās izpētes komisijas raksti, 1. sējums, 147-204. https://www.lu.lv/fileadmin/user_upload/lu_portal/projekti/vdkkomisija/VDKkomisija_raksti_1sejums_Totalitarisma-sabiedribas-kontrole-un-represijas_2016-0330marts.pdf (skatīts 01.08.2020.)

3 Zanda Mankusa, "Over the Iron Curtain: the Evangelical Lutheran Church of Latvia Meets the West", Journal of Baltic Studies 37:3 (2006), 313-335.

4 Linards Rozentāls, "Izdzīvošana: Sinodālais pāvaldes princips Latvijas Evaņgéliski luteriskajā baznīcā 1948.-1984. gadā”, Opera Theologica Universitatis Latviensis, Tomus III (Rīga: LU Akadēmiskais apgāds, 2017).

5 Jouko Talonens, Baznīca staļinisma žņaugos: Latvijas Evangééliski luteriskā baznīca padomju okupācijas laikā no 1944. līdz 1950. gadam (Rīga: Luterisma mantojuma fonds, 2009).

6 Edgars Rumba, “Angḷ viesi Latvijā”, Jaunākās Ziņas 135 (18.06.1938.), 2.

7 Edgars Rumba, "Sarunas ar Anglijas baznīcas pārstāvjiem”, Cel̦ 4 (1938), 234-235.

8 Vēlāk, pēc PSRS invāzijas Ungārijā un N̦. Hruščova runas PSKP XX kongresā (1956. g.) viņš sāka raudzīties kritiskāk uz sociālismu. Sešdesmitajos gados publicētā grāmatā S. Evanss kritizēja L̦eņinu un Staļinu par vardarbības sludināšanu un par vienkāršotu izpratni par šķirām. Citās vietās grāmatā atklājas vienpusīga pieeja - S. Evanss atsaucas uz pareizticīgo "atjaunotās baznīcas" 1923. gada koncila Maskavā rezolūciju, ka pasaulē ir divas šķiras - ekspluatatori un proletariāts. Kapitālismu koncils pasludināja par nāves grēku un cīnu pret to - par kristieša svēto pienākumu. Grāmatā nav sniegta kritiska "atjaunotās baznīcas" analīze. Stanley G. Evans, The Social Hope of Christian Church (London: Hodder and Stoughton, 1965), 211, 238-241. 
pirms nāvessoda izpildes par spiegošanu PSRS uzdevumā notiesātajam Rozenbergu pārim ASV prasīja, lai premjerministrs izmantotu savu ietekmi un lūgtu viņus apžēlot. Šo un citu politisko aktivitāšu dēl S. Evansam bija grūti atrast darbu Anglijas baznīcā. ${ }^{9}$ S. Evanss nebija pirmais un pazīstamākais komunisma idejām simpatizējošais britu mācītājs, kas apmeklēja PSRS. Britu mediju telpā viskontraversālākais bija Kenterberijas katedrāles dekāns Hjulets Džonsons (Hewlett Johnson), kas bija vairākkārt apmeklējis PSRS un citas Austrumu bloka zemes. 1945. gadā viņš satikās ar Josifu Stalıinu un Vjačeslavu Molotovu. Pat pēc tam, kad PSRS publiski nosodija Stalıina kultu, Džonsons bija starp tiem, kas kritizēja N̦. Hruščovu par to. ${ }^{10}$ Interesants ir fakts, ka 1945. gadā viņa bisti veidoja slavenā Latvijā dzimusī tēlniece Vera Muhina. ${ }^{11}$ Džonsona atbalsts PSRS un citiem līdzīgiem režīmiem izraisijja asus konfliktus ar britu valsts iestādēm, Anglijas baznīcu, pat mēǵinājumu viņu atstādināt no garīdznieka amata. Viņa paša privātā dzīve neatbilda komunistiskajiem ideāliem, kurus viņš aizstāvēja, - Londonā viņam piederēja divas ēkas, kā arī īpašumi Kenterberijā un citur. ${ }^{12}$

Lielbritānijas-PSRS asociācijas delegācija 1946. gadā apmeklēja Jāņa baznīcu Rīgā, kā arī tikās ar LELB vadību. Tikšanās ar baznīcu pārstāvjiem nebija primārais britu delegācijas mērķis, un arī padomju puse to publiskajā telpā noklusēja. Laikrakstā "Cīņa" ievietotajā informācijā S. Evanss ir saukts par Anglu-padomju biedrības priekšsēdētāju, viņa garīdznieka amats nav minēts, tāpat nav ne vārda par delegācijas locekḷu tikšanos ar kristīgo konfesiju pārstāvjiem. ${ }^{13}$ Vēlāk vingš britu anglikāṇu laikrakstā publicēja vēstuli, kurā apgalvots, ka baznīca Padomju Latvijā netiek vajāta. Viņš pats personīgi 1946. gada vasarā esot pastaigājies pa Rīgu kopā ar katoḷu garīdzniekiem, kuri bijuši sutanās. Katol̦u semināra rektors Pēteris Strods viņam teicis, ka garīdznieki var brīvi administrēt sakramentus mājās un slimnīcās un ticīgie apmeklē Aglonu tikpat lielā skaitā kā pirms kara. Vēstulē arī pausts padomju propagandas tiražētais apgalvojums, ka Latviju pametušais luterāṇu arhibīskaps Teodors Grīnbergs bija kolaboracionists. ${ }^{14}$ Par minētās delegācijas vizīti Rīgā ir saglabājusies Latvijas PSR Ārlietu ministrijas lieta, kurā ir ne tikai vizītes programma, bet arī precīzas instrukcijas par to, kas ekskursiju un

9 Dianne Kirby, "Ecclesiastical McCarthyism: Cold War Repression in the Church of England", Contemporary British History 19:2 (2005), 195-196.

10 Robert Hughes, The Red Dean: The Life and Riddle of D. Hewlett Johnson, born 1874, died 1966, Dean of Canterbury 1931 to 1963 (Worthing: Churchman Publishing, 1987), 135, 169; 1939. gadā viņš nosodīja PSRS iebrukumu Somijā kā tādu, "kuram nav morāla attaisnojuma", taču arī tad piesardzīgi, aicinot kritiku nepārvērst "pasaules krusta karā pret PSRS”. Ibid., 104-106.

11 “The Busted Dean”, Church Times CXXVIII: 4297 (01.06.1945.), 310.

12 Robert Hughes, The Red Dean: The Life and Riddle of D. Hewlett Johnson, born 1874, died 1966, Dean of Canterbury 1931 to 1963, 178.

13 "Par Anglu u-padomju biedrības delegācijas uzturēšanos Rīgā”, Ciña 165 (17.07.1946.), 4.

14 Stanley Evans, “Latvia”, Church Times CXXX: 4390 (28.03.1947.), 171. 
tikšanos laikā sakāms, kādi akcenti liekami vēstures izklāstā. Vizītes laikā bija jāstāsta par to, kā "latviešu tautu apspieduši vācu iekarotāji, baroni un junkeri, par gadsimtiem ilgo latviešu tautas naidu pret vācu paverdzinātājiem, par kopīgo latviešu un krievu tautu cinnu pret vācu apspiedējiem"15. Starp minētās lietas dokumentiem ir arī Reliǵgijas kultu lietu padomes (RKLP) pilnvarotā Voldemāra Šeškena parakstīta izziņa, kurā uzskaitīti reliǵisko organizāciju pārstāvji, ar kuriem viesu intereses gadījumā organizēt tikšanos. Starp tiem minēti G. Tūrs (tolaik LELB arhibīskapa vietas izpildītājs) un viņa kā baznīcas virsvaldes prezidenta vietnieks mācītājs Arvīds Kauliņš. Interesants ir V. Šeškena sniegtais abu LELB vadītāju raksturojums - "nekādas iepriekšējas sarunas ar viņiem nevajag vest, jo viņi pietiekami sevi parādījuši, kā padomju patrioti”"16. Par P. Strodu ir teikts, ka viņš izteicies, ka seminārā gatavojot padomju patriotus un pēc savas iniciatīvas pasniedz padomju konstitūcijas pamatus. ${ }^{17}$ Par baptistu draudžu vecāko prezbiteru Baltijas republikās Nikolaju L̦evindanto teikts, ka "viņš stāv stingrās padomju pozīcijās" ${ }^{18}$. V. Šeškens izziņas beigās piesardzīgi raksta, ka "Rīgā ir tikai viena anglikāņu baznīca. (...) Šai baznīcai saprotamu iemeslu dēl neviens roku nav pielicis un pilnvarotā pārvalde tai pat tuvojusies nav." ${ }^{19}$ Pēc delegācijas vizītes sniegtā atskaitē atrodamie baznīcu vadītāju izteikumi par religijijas brīvību PSRS kontrastē ar to, ka pirms dažiem mēnešiem tika arestēti LELB arhibīskapa vietas izpildītājs Kārlis Irbe un baptistu bīskaps Kārlis Lāceklis. Valsts amatpersonu atskaitē pēc delegācijas vizītes sīki aprakstīts sarunās klātesošo teiktais un vinu rīcība, cik veiksmīgi viņi izpildījuši uzdotās lomas. Par Tūru teikts, ka uz jautājumu par to, kā ar iespējām baznīcai izdot grāmatas, viņš atbildējis "pēc nelielas aizķeršanās"20. Par luterāņu un katoḷu baznīcu pārstāvju izturēšanos atskaitē kopumā sniegts pozitīvs vērtējums - "šajos apmeklējumos delegāti pārliecinājās, ka pilsoņiem šeit ir sniegta iespēja pilnīgi brīvi izpildīt reliǵiskos kultus"21. Piebilsts gan, ka delegācijas locekḷiem šķitis, ka katoḷi viņus uzņem pārāk vēsi. ${ }^{22} \mathrm{G}$. Tūrs sarunās teica, ka PSRS valda reliǵijas brīīība un mācītāju apcietināšanai nav sakara ar

\footnotetext{
15 "Angḷ u-padomju vienotības" atbraukšanai, bez datuma, [krievu val.], Latvijas Nacionālais arhīvs - Latvijas Valsts arhīvs (LNA-LVA), 1051-1a-8, 4.

16 RKLP pilnvarotā Šeškena izziṇa, 12.07.1946., [krievu val.], LNA-LVA, 1051-1a-8, 18.

17 Ibid.

18 Ibid.

19 Ibid., 19.

20 Atskaite par delegācijas vizīti, [krievu val.], LNA-LVA, 1051-1a-8, 26. (nedatēta atskaite bez autora norādes).

21 Ibid., 29.

22 Ibid.
} 
reliǵisko organizāciju darbības ierobežošanu. Vinsš arī optimistiski teica, ka LELB drīz būs savs Teoloğijas institūts. ${ }^{23}$

Piecdesmitajos gados abu pušu kontaktiem lielākas iespējas radīja destalılinizācijas process PSRS, Lielbritānijas un PSRS attiecību uzlabošanās posmi (1956. g. Lielbritāniju apmeklēja padomju delegācija Ņikitas Hruščova vadībā), kas mijās ar aukstajam karam raksturīgo spriedzes eskalāciju. Ārpus PSRS biežāk sāka braukt ne tikai Krievu pareizticīgās baznīcas (KPB), bet arī citu konfesiju delegācijas. 1951. gadā ar anglu kvēkeru starpniecību tika atjaunoti sakari starp britu un padomju baptistiem. 1953. gadā, dažus mēnešus pēc Staļina nāves, Stokholmā viesojās četri baptisti no PSRS. Tolaik padomju delegācijas pamatinterese bija nodrošināt atbalstu Vispasaules miera padomei. ${ }^{24}$

Tālāk šajā tekstā aprakstītā PSRS garīdznieku delegācijas vizīte (1955. g.) notika laikā, kas Lielbritānijā bija lielu ekumenisku cerību laiks, kad par ekumenismu runāja pat parlamentā. 1955. gadā Anglijas baznīcas konvokācijas ${ }^{25}$ debatēja par episkopālo un neepiskopālo konfesiju apvienošanos Dienvidindijā (1947. gadā tika dibināta Dienvidindijas baznīca), tajā pašā gadā sākās oficiālas sarunas par britu metodistu un anglikāņu apvienošanos (līdz šim neīstenota), 1958. gadā Lambetas konference ${ }^{26}$ pasludināja, ka izlīgums ir galvenā prioritāte. 1960. gadā Kenterberijas arhibīskaps Džefrijs Fišers (Fisher) devās uz Romu, lai satiktu pāvestu, kas bija pirmā šāda līmeņa tikšanās kopš Reformācijas. Aukstā kara spriedzes apstākḷos dalı baznīcu līderu uzskatīja, ka ekumenisms ir labs paraugs politiksiem. Ekumenisko ideju izplatību tā laika sabiedrībā tomēr nevajadzētu pārspīlēt - garīdznieki bija tajās vairāk ieinteresēti nekā laji, un daudzi anglokatoḷi un konservatīvie evaņgélikālsi bija pret. ${ }^{27}$

23 Jouko Talonens, Baznīca stalinisma žņaugos: Latvijas Evanğgéliski luteriskā baznīca padomu okupācijas laikā no 1944. līdz 1950. gadam, 98. LELB jau kopš kara beigām centās panākt aț̣auju dibināt teoloǵisku mācību iestādi, taču tolaik nesekmīgi.

24 W. M. S. West, To Be a Pilgrim: a Memoir of Ernest A. Payne (Guildford: Lutterworth Press, 1983), 93. Pirms tam padomju baptistu delegācija ārzemēs bija 1946. gadā Stokholmā. Istorija jevangelskih hristian-baptistov v SSSR (Moskva: Vsesojuznij sovet jevangelskih hristian-baptistov, 1989), 255.

25 Jorkas un Kenterberijas konvokācijas - sinodālas divu Anglijas baznīcas provinču garīdzniecības pārstāvju sanāksmes.

26 Lambetas konference - pasaules anglikāņu bīskapu sanāksme, kuru Kenterberijas arhibīskaps parasti sasauc reizi desmit gados.

27 Sam Brewitt-Taylor, Christian Radicalism in the Church of England and the Invention of the British Sixties, 1957-1970: The Hope of a World Transformed (Oxford: Oxford University Press, 2018), 114-115. 


\section{G. Tūra vizīte Lielbritānijā 1955. gadā}

Uz Lielbritāniju 1955. gada jūlijā devās delegācija, kuras sastāvā bija četri pareizticīgie, divi baptisti, divi luterāņi. Cel̦ojumā divu nedēḷu laikā tā apmeklēja gan Angliju, gan Skotiju. ${ }^{28}$ "Teologiija un golfs" - tā trāpīgi vizītes programmu nosauca "The Times", pieminot, ka delegācija iepazinās ar britu elites kultūru apmeklēja golfa čempionātu un viesojās universitātēs. ${ }^{29}$

Britu puse plānoja padomju garīdznieku delegācijas vizīti saziņā ar savas valsts ārlietu dienestu, sīki pārdomājot detaļas. Lielbritānijas Ārlietu ministrijas attieksme pret okupēto Baltijas valstu statusu un to iedzīvotāju diasporas organizācijām pēckara gados bija piesardzīga un mainījās atkarībā no valdības nostājas. Kad 1946. gadā Anglijas baznīca prasīja Ārlietu ministrijas viedokli par sakariem ar latviešu un igauņu luterāņu baznīcām diasporā, atbilde bija, ka britu valdība ir de facto atzinusi šo valstu okupāciju (tekstā teikts “inkorporāciju”). Lai arī tā nav atzīta de iure, britu valdība neredz iespējas, ka šo valstu neatkarība varētu tikt atjaunota un bijušie šo valstu baznīcu vadītāji atgūt savus amatus. Līdz ar to Ārlietu ministrija ieteica Anglijas baznīcai veidot attiecības ar baznīcām Latvijā un Igaunijā, kontaktējoties ar tām tieši, bez padomju iestāžu starpniecības, un ar baznīcu vadītājiem trimdā saglabāt tikai tīri personiskas attiecības. ${ }^{30}$ Šajā viedoklī atspoguļojās fakts, ka Lielbritānijas valdība kara laikā un pirmajos pēckara gados attiecībās ar PSRS centās izvairīties no konfrontācijas. Kad 1944. gadā "New Chronicle" korespondents Maskavā Pols Vintertons (Winterton) informēja redaktoru par padomju varas brutalitāti un iespējamām Baltijas republiku iedzīvotāju deportācijām, Ārlietu ministrija parūpējās, lai šīs ziñas netiktu publicētas. ${ }^{31}$ Ernests Bevins (Bevin), kas bija britu ārlietu ministrs laikā no 1945. līdz 1951. gadam, sākotnēji cerēja, ka PSRS pret leiboristu valdību būs draudzīgāka nekā pret konservatīvo valdību. ${ }^{32}$ Britu ārpolitika mainījās 1948. gada sākumā, kad E. Bevins atklāti pazingoja par to, ka jāatzīst Eiropas sadalīīība un padomju politisko centienu neitralizācijai ar britu domīniju un ASV atbalstu pretī jāliek "formāla vai neformāla" Rietumeiropas vienotība. Vinsš

\footnotetext{
28 “England", Living Church CXXXI: 4 (24.07.1955.), 7.

29 "Soviet Church Delegates", The Times (25.06.1955.), 4.

30 Robin Hankey, Confidential Letter to Waddams, 31.12.1946., Lambeth Palace Library, CFR LRC 93, Latvia: General Situation, 20.03.1944.-07.10.1976., 26. Robins Hankijs (Hankey) kā Ārlietu ministrijas Ziemel̦u departamenta direktors bija iesaistīts Krievijas komitejā, pie kuras piederēja galvenie ministrijas ierēdņi un kura nodarbojās ar padomju ārpolitikas analīzi. Ray Merrick, "Russia Committee of the British Foreign Office and the Cold War, 1946-47", Journal of Contemporary History 20: 3 (1985), 467.
}

31 Craig Gerrard, "Britain and the Baltic States. The Late 1940s and the early 1990s", The Baltic Question During the Cold War ed. John Hiden, Vahur Made, David Smith (Abingdon, New York: Routledge, 2008), 76.

32 Ray Merrick, "Russia Committee of the British Foreign Office and the Cold War, 1946-47", 458. 
arī, izmantojot aukstā kara retoriku, runāja par "Rietumu civilizācijai piemītošo ētisko un garīgo spēku konsolidāciju”, pasludinot Lielbritāniju par tās galveno aizstāvi. ${ }^{33}$ Britu izlūkdienests M16 laikā no 1949. līdz 1956. gadam ar vācu jūrnieku palīdzību sūtīja baltiešu emigrantus kā aǵentus vispirms uz Latviju un tad arī Lietuvu un Igauniju, lai viñi kontaktētos ar pretošanās kustību. Tur viņus pārtvēra padomju drošības iestādes. ${ }^{34}$

1955. gadā, atbildot uz Anglijas baznīcas vēlmi noskaidrot, vai ir pieņemami sūtīt Latvijas un Igaunijas luterisko baznīcu vadītājiem ielūguma vēstuli ar Maskavas patriarhāta starpniecību, Ārlietu ministrijas pārstāvis atbildēja apstiprinoši, jo tas saskanot ar to, ka britu valdība de facto ir atzinusi šo valstu aneksiju..$^{35}$ Tomēr līdzās KPB sūtītam Britu baznīcu padomes ielūgumam $\mathrm{G}$. Tūram tika nosūtìta arī Kenterberijas arhibīskapa vēstule, diplomātiski piedāvājot ieklạuties KPB pārstāvja vadītās delegācijas sastāvā vai braukt atsevišķi un atsaucoties uz pirmskara sarunām starp baznīcām Anglijā, Latvijā un Igaunijā. ${ }^{36}$

ledrošināt Austrumu bloka baznīcas - tas bija viens no Anglijas baznīcas motīviem PSRS garīdznieku delegācijas aicināšanā. Lai arī tas neizskanēja oficiālajās runās, anglikāņu baznīcas amatpersonas dalēeji bija informētas par ticīgo vajāšanām PSRS un tās satelītvalstīs, lai gan ticamu un līdzsvarotu informāciju nebija viegli iegūt. Padomju puses labi finansētie ārzemnieku braucieni uz PSRS radijja vienpusīgu iespaidu. Piemēram, tajā pašā 1955. gadā anglikāņu garīdznieku grupa atgriezās no šāda celıojuma, kas notika pēc patriarha Aleksija ielūguma, un stāstijja, ka valsts un baznīcas attiecības padomju valstī ir draudzīgas un izpaužas kā "mierīga līdzāspastāvēšana" ${ }^{37}$. Vēl kara laikā Anglijas baznīcas Ārlietu padomes generālsekretārs Herberts M. Vadamss (Waddams) "Krievijas grupai", komentējot cel̦ojumā uz PSRS piedzīvoto, teica, ka vinu pārsteidzis gan optimistiskais turienes baznīcas skatijums, gan iespējas, kādas KPB dotas izdevējdarbībā. ${ }^{38}$ Tā bija padomju propagandas veiksme, jo pretēji radītajam iespaidam baznīcas izdevējdarbība atradās stingrā valdības kontrolē un kalpoja tās mērḳiem.

33 Ray Merrick, "Russia Committee of the British Foreign Office and the Cold War, 1946-47", 464.

34 Beatrice Heuser, "Covert action within British and American concepts of containment, 1948-51", British Intelligence, Strategy and the Cold War, 1945-51, ed. Richard J. Aldrich (London, New York: Routledge, 2005), 72.

35 The Foreign Office Letter to Herbert Waddams, 04.02.1955., Lambeth Palace Library, CFR LRC 95/1, Latvia: Contacts: Archbishop Turs. 10.01.1955.-20.03.1973., 3.

36 Archbishop's of Canterbury Letter to G. Turs, 19.02.1955., Ibid., 4.

37 “Russia. Peaceful Co-existence", Living Church CXXXI: 4 (24.07.1955.), 7.

38 Russia group. Notes of a meeting (08.12.1943.), Lambeth Palace Library, CFR G 9/1, 1941-1963, Communism: Russia, 36op; "Krievijas grupa" bija neformāla dažādu konfesiju, Britu un ārzemju Bībeles biedrības un valdības iestāžu darbinieku (baptistu mācītājs Hjū Martins (Martin) strādāja Informācijas ministrijā) kopa, kas bija izveidota, lai apmainītos ar informāciju par PSRS notiekošo un izstrādātu kopīgu attieksmi. 
Piemēram, grāmatas “Patiesība par reliǵiju Krievijā” izdošanu kā pretsvaru tam, ka pareizticīgo baznīcu propagandai izmantoja nacisti, Staļinam rekomendēja iekšlietu tautas komisārs Lavrentijs Berija. Lēmumu par to 1942. gada 10. martā pieņēma Kompartijas politbirojs. ${ }^{39}$ Grāmatas sākumā deklarēts, ka tā atbildēs uz jautājumu, vai baznīca PSRS uzskata sevi par vajātu. ${ }^{40}$ Sākumā bija plānots, ka grezni iesieto sējumu izdos sekulāra izdevniecība, bet tad lielākas ticamības panākšanai to uzticēja KPB. PSRS ārlietu politikas veidotāji lika uz šo izdevumu lielas cerības, ne velti tas tika nosūtīts arī ASV viceprezidentam un valsts sekretāram, vairāku ASV pilsētu mēriem. ${ }^{41}$

Tomēr Lielbritānijā bija pieejama arī cita informācija - Britu baznīcu padomes Ārlietu nodaļa sagatavoja dokumentu krājumu par relig̣isko organizāciju stāvokli Austrumeiropā. Priekšvārdu grāmatai rakstīja Kenterberijas arhibīskaps Dž. Fišers, ievadu - H. Vadamss. Grāmatā ir galvenokārt dokumentu tulkojumi (piem., izvilkumi no PSRS konstitūcijas un citiem tiesību aktiem) un īsi komentāri. Tajos ir arī kritika atzīts, ka līdz ar padomju armijas ienākšanu tagadējā Rietumukrainā uniāti tika spiesti "atteikties no lojalitātes Romai un pievienoties Krievu pareizticīgajai baznīcai”42. Tāpat atzīta augošā antireliğiskā propaganda, kā arī tendence pastiprināt KPB sakarus un ietekmi attiecībās ar citām pareizticīgo baznīcām (kā piemērus minot centienus paklaut Rietumeiropas un Ziemeļamerikas pareizticīgos kanoniskai piederībai Maskavas patriarhātam, kā arī faktu, ka 1946. gadā Čehoslovākijas Pareizticīgā baznīca no Serbijas patriarhāta pārgāja Maskavas patriarhāta jurisdikcijā). ${ }^{43}$

Anglijas baznīcas ārlietu padomes asociētais sekretārs Džons Findlovs (Findlow) tolaik slepenā ziņojumā pēc padomju garīdznieku 1955. gada vizītes rakstīja: "Lai gan viņi ir atgriezušies savā būrī un durvis atkal ir aizvērušās, ir pamats cerībai, ka durvis atkal atvērsies iebraukšanai un izbraukšanai, un mēs vismaz zinām, ka tagad mūs vairāk kas

39 Mihail Odincov, Anna Kochetkova, Konfesionalnaja politika $v$ Sovetskom Sojuze $v$ godi Velikoi Otecesstvennoi voini 1941-1945 gg. (Moskva: Nauhcno-politicheskaja kniga; Politicheskaja enciklopedija, 2014), 127.

40 Sergij (Stragorodskij), "Predislovije”, Pravda o religii v Rossii (Moskva: Moskovskaja Patriarhija, 1942), 7.

41 Anatoly Kashevarov, "Chastichnoe vozrozhdenie i osobennosti cerkovnoj pechati v 1940-e gody”, Hristianskoe chtenie 4 (2016), 191-192. http://christian-reading.info/data/2016/04/201604-09.pdf

42 J. B. Barron, H. M. Waddams, Communism and the Churches: A Documentation (London: SCM Press, 1950), 29.

43 Ibid., 28-29. Process, kas grāmatā diplomātiski apzīmēts par pāriešanu Maskavas patriarhāta jurisdikcijā, notika politiskā spiediena uz Serbijas pareizticīgo baznīcu rezultātā. Serbijas baznīca sākotnēji uzskatijja pāreju par nekanonisku, jo tā nebija notikusi saziñā ar šo baznīcu (Daniela Kalkandjieva, The Russian Orthodox Church, 1917-1948: From Decline to Resurrection (London, New York: Routledge, 2015), 281-282). 
vieno (...), nekā šķir." ${ }^{44}$ Dž. Findlovs arī pieminēja metropolīta Pitirima "pārcenšanos", preses konferencē sakot, ka PSRS nepastāv antireligiska propaganda. Pat oficiālā tulce šo teikumu izlaida. ${ }^{45}$ Ziņojumā ir arī Dž. Findlova pārdomas par to, kas varētu būt padomju iestāžu atsūtītais delegācijas novērotājs. Viñam sākumā licies, ka tā varētu būt tulce, bet vēlāk - baptistu pārstāvis N. L̦evindanto. ${ }^{46}$ Ziņojumā netrūkst arī neformālu detaļu - kā pēdējā vakarā metropolìta istabā viņi dzēruši pa kārtai no zobu pastai domātas glāzes G. Tūra atnestu brendija pudeli. ${ }^{47}$ Ziņojumā pausts optimisms, kas vēlāk izrādijās pārlieks. Dž. Findlovs, piemēram, kā ilustrāciju pārmaiņām padomju politikā min faktu, ka metropolīts un padomju vēstnieks pieņemšanā PSRS vēstniecībā stāvēja kopā un ka vēstnieks pozitīvi izteicies par iespējamo pareizticīgo un anglikāņu vienošanos ${ }^{48}$ Tādējādi gan rakstītājs ignorēja to, ka vēl pirms dažiem gadiem, pareizticīgo baznīcu sanāksmē Maskavā 1948. gadā, tika pieņemta rezolūcija, kas noraidijja iespēju atzīt anglikāņu ordinācijas (pamatojot ar to, ka garīgo amatu atzǐšanas pamatā ir vienotība mācībā, bet anglikāņu ticības apliecība "39 artikuli” krasi atšķiras no pareizticības dogmām). ${ }^{49}$ 1955. gada vizītes laikā Londonā notika pareizticīgo un anglikāṇu sarunas, kuru tonis bija pozitīvs, taču nekādi konkrēti rezultāti sasniegti netika. ${ }^{50}$

Vizītes gatavošana padomu pusē bija sarežğìtāks process, jo PSRS reliǵisko organizāciju pārstāvju ārzemju braucienu un ārzemju delegāciju uzņemšanas saskaņošana bija vairāku valsts un partijas iestāžu ziņā. To viedokḷi dažkārt atšķ̄īās - piemēram, 1948. gadā RKLP atbalstijja padomju rabīnu vizīti uz Poliju sakarā ar Varšavas geto

44 John Findlow, Russian Delegation Reports, Lambeth Palace Library, CFR LRC 95/1, Latvia: Contacts: Archbishop Turs, 10.01.1955.-20.03.1973., 17.

45 Ibid., 17op-18.

46 Ibid., 20op-21.

47 Ibid., 20op.

48 Ibid., 17op.

49 "Resolution on the Question of "The Anglican Hierarchy", Major Portions of the Proceedings of the Conference of the Heads of the Autocephalous Orthodox Churches in Conncetion with the Celebration of 500 Years of Autocephalicity of the Russian Orthodox Church (Paris: YMCA Press, 1952), 239. Minētās konferences debatēs līdzās teoloǵiskiem argumentiem bija arī politiski (atsauces uz britu imperiālismu) un sazvērestības teorijās (par masonu ietekmi) balstīti argumenti. "Meetings of the Commission on the Question "Concerning the Anglican Hierarchy"”, Ibid., 182-207.

50 Ceḷojuma atskaitē "Maskavas Patriarhāta Žurnālā” par šìm sarunām ir divi īsi paragrāfi, kuros teikts, ka delegācijas runājušas četras stundas un vienojušās, kuras abu baznīcu doktrīnas nākotnē sīkāk jāapspriež. Atskaite kopumā atgādina jūsmīgu stāstījumu par redzētiem dabas un kultūras objektiem. N. Uspenskij, "Dve nedeli v Anglii”, Zhurnal Moskovskoi Patriarhii 9 (1955), 70-78. 
sacelšanās piekto gadadienu, bet Valsts drošības ministrija noraidīja. ${ }^{51}$ Varasiestāžu lēmumi bija atkarīgi no padomju ārpolitikas prioritātēm, braucēju uzticamības, iespējamas saskarsmes ar nevēlamām personām, potenciāliem apdraudējumiem padomju varas prestižam. Šajā rakstā aplūkotās vizītes sagatavošanas aizkulises atklāj RKLP pilnvarotā Latvijas PSR arhīva lietas - brauciens visos sīkumos tika saskaņots ar varas iestādēm. Par ielūgumu apmeklēt Lielbritāniju G. Tūrs rakstijja pilnvarotajam, lūdzot pirms baznīcas virsvaldes sēdes, kurā bija plānots šo jautājumu skatīt, sniegt aț̣auju. lelūgumu G. Tūrs bija saņēmis ar KPB metropolīta Nikolaja starpniecību (G. Tūra lūgumrakstā minēts, ka Nikolajs ir Vispasaules miera padomes loceklis). G. Tūrs labi apzinājās, kas bija tolaik padomju politikā pieņemamā retorika - vajadzību pieņemt ielūgumu G. Tūrs pamatoja ar to, ka "šāds brauciens veicinās mieru un tautu draudzību, kas saskan ar tālredzīgo un miermīlīgo Padomju Savienības ārpolitiku"52. Kā raksta kultūrvēsturnieks Jevgeņijs Dobrenko (Lielbritānija), pēc Otrā pasaules kara cīņa par mieru padomju ideolog̣ijā kḷuva svarīgāka par šķiru cīṇu. "Cịna par mieru kḷuva par padomju dēmonolog̣ijas pamatu - ienaidnieks tagad noteikti bija miera pretinieks un kara kurinātājs." 53

G. Tūrs vēlāk Maskavā satikās ar RKLP priekšsēdētāju Ivanu Poḷanski, kas viņam paziņoja, ka padomju valdība aț̣̄āvusi braukt. Sarunā I. Poḷanskis teica (sarunas protokolā lietots vārds "rekomendēja") G. Tūram, lai viņš brauciena laikā nepieņemtu nekādus lēmumus par attiecībām ar anglikāņiem, bet tikai pēc atgriešanās Latvijā. lespējams, tā bija reakcija uz LELB vadības entuziasmu par attiecību ar anglikāņiem atjaunošanu. Baznīcas virsvalde vienā no sēdēm iepazinās ar 1938. gada vienošanās saturu un to vēlreiz aprobēja. ${ }^{54}$ LELB vadībai acīmredzot bija būtisks šis kopīgās sadraudzības akts G. Tūrs vēlāk rakstā par vizīti baznīcas kalendārā pieminēja, ka Latvijas un Igaunijas arhibīskaps saṇēma svēto vakarēdienu no Kenterberijas arhibīskapa kā apliecinājumu interkomūnijai. ${ }^{55}$

51 Nikita Pivovarov, "What Kind of Religious Persons Were Invited to the USSR, and Who Was Allowed to Go Abroad (1943-1985)", State, Religion and Church 4:2 (2017), 96. https:// pdfs.semanticscholar.org/213b/5bd55a2742e2e970ad744b1da35bddddb200.pdf?_ga=2. 224093151.592533201.1597945592-641591829.1597945592 (skatīts 19.08.2020.)

52 Latvijas PSR Evaņgēeliski luteriskās baznīcas virsvaldes prezidenta, arhibīskapa Gustava Tūra vēstule PSRS Ministru padomes Religijas kultu lietu padomes pilnvarotajam Latvijas PSR [krievu val.], 22.03.1955., LNA-LVA, 1448-1-7, 45.

53 Jevgenij Dobrenko, Pozdnij stalinizm: estetika politiki, t. 2 (Moskva: Novoje literaturnoje obozrenije, 2020), 382.

54 Latvijas PSR Ev. lut. baznīcas virsvaldes plenārsēžu protokoli (24.01.1952.-16.11.1959.), LELB arhīvs, 1-3-41, Protokols Nr. 28, 04.05.1955., 94-95.

55 Arhibīskaps Gustavs Tūrs, "Arhibīskapa atskaite draudzēm par viṇa ceḷjumu uz Lielbritāniju 1955. g. no 4.-18. jūlijam”, Latvijas Evañgéliskās luteriskās baznīcas kalendārs 1956. gadam (Rīga: b. i, b. g.), 42. 
I. Poḷanskis sarunā teica, lai G. Tūrs "uzvestos ārzemēs ar padomju pilsoņiem pienākošos cieņu, jo tur pret padomju cilvēkiem tiks izrādīta paaugstināta interese" ${ }^{\text {. }}$. Šis ieteikums bija līdzīgs frāzēm instrukcijās, kuras pirms ārzemju braucieniem sañēma PSRS pilsoñi. Piemēram, trīs musulmaņus, kuri 1955. gadā devās studēt uz Kairu (Ēğipte), RKLP informēja, ka viniem "nav ieteicams veidot šaubīgas paziššnās un apmeklēt dažādas nakts izklaides vietas". Turpat arī teikts, ka viņiem jāatspēko "launprātīga vēršanās pret padomju tautu, padomju valdību vai valsti”" ${ }^{\prime 7}$.

No protokola redzams, ka minēto tikšanos G. Tūrs izmantoja, lai lūgtu atḷauju atvērt Rīgas Jaunās Ģertrūdes draudzes telpās semināru ar četrgadīgu apmācību 30-40 cilvēkiem. ${ }^{58}$ I. Poḷanskis gan neko konkrētu nesolija, tikai teica, ka izskatīs jautājumu..$^{59}$ Tajā pašã gadā RKLP pilnvarotais Jūlijs Restbergs ziņojumā I. Poḷanskim, Latvijas PSR kompartijas sekretāram Arvīdam Pelšem un Ministru padomes priekšsēdētāja vietniekam Eduardam Berklavam skaidroja teologiiskās mācību iestādes atvēršanas vilcināšanu ar to, ka G. Tūrs iesniedzis nekvalitatīvus materiālus par paredzēto mācību iestādi. Tālāk seko teikums, ka "ieinteresēts šajā jautājumā ir G. Tūrs, tāpēc uzskatu, ka mums nevajag no savas puses izrādīt interesi par jautājuma forsēšanu"60.

G. Tūrs par ielūgumu ziñoja arī baznīcas virsvaldes plenārsēdē. Protokola teksts formāls - virsvalde vienbalsīgi piekrīt atsaukties ielūgumam un izsaka vēlēšanos, ka G. Tūrs brauktu kopā ar citu konfesiju garīdzniekiem. Lēmumā vēl izteikts vēlāk tomēr neīstenots priekšlikums, ka G. Tūru pavadītu kāds no LELB prāvestiem, kas prot angḷu valodu. ${ }^{61}$

56 PSRS Ministru padomes Reliǵijas kultu lietu padomes priekšsēdētāja I. Poḷanska tikšanās ar Evañgéliski luteriskās baznīcas Latvijas PSR arhibīskapu G Tūru pieraksts [krievu val.], 14.05.1955., LNA-LVA, 1448-1-7, 64.

57 "Nakaz Soveta po delam religioznih kultov studentam-musulmanam, napravlennim dlja obuchenija v Kairskij universitet al-Azhar. Sentjabrj 1955. g.", Islam i sovetskoje gosudarsrtvo (19441990). Sbornik dokumentov, Vip. 3, sost. Dmitirj Yu. Arapov (Moskva: Izdatelskij dom Mardzani, 2011), 117.

58 PSRS Ministru padomes Reliǵijas kultu lietu padomes priekšsēdētāja I. Poḷanska tikšanās ar Evaņgéliski luteriskās baznīcas Latvijas PSR arhibīskapu G. Tūru pieraksts [krievu val.], 14.05.1955., LNA-LVA, 1448-1-7, 64.

59 Ibid., 65.

60 J. Restbergs. Ziņojums par reliǵisko kultu darbību un stāvokli Latvijas PSR 1955. gada pirmajā pusē [krievu val.], 22.07.1955., LNA-LVA, 1448-1-254, 67. No 1954. g. janvāra LELB pastāvēja Akadēmiskie teoloğiskie kursi (rektors G. Tūrs, inspektors P. Kleperis), kuri eksistēja līdz to reorganizācijai 1969. gadā, taču LELB vēlējās izveidot augstākās izglītības mācību iestādi un tāpēc turpināja uzturēt prasību par semināra izveidi. Zanda Mankusa, "Latvijas Evangéēliski-luteriskās baznīcas mācītāju darbība laika posmā no 1954. līdz 1964. gadam”, Ceḷš 53 (2001), 56-58.

61 Latvijas PSR Ev. lut. baznīcas virsvaldes plenārsēžu protokoli (24.01.1952.-16.11.1959.), LELB arhīvs, 1-3-41, Protokols Nr. 27, 29.03.1955., 90op. 
Delegācijas sastāvā bez G. Tūra bija vēl viens garīdznieks no Latvijas - jau pieminētais evanggélisko kristiešu baptistu vecākais prezbiteris Baltijas republikās N. Ļevindanto. Viņš no padomju varasiestāžu viedokḷa bija piemērots kandidāts ārzemju braucieniem. Pilnvaroto ziñojumos L̦evindanto raksturots kā paklausīgs padomju sistēmai, kas neiebilst pret draudžu slēgšanu - "lojāli attiecas pret mūsu pasākumiem un neizrāda īpašu aktivitāti”" . Vinš gan pats vairākkārt sodīts - 1924. un 1927. gadā administratīvi, izsūtot no Maskavas pirmajā reizē uz diviem gadiem ("par pretkara darbību"), otrajā - uz trim, 1934. gadā - ar ieslodzijumu darba nometnē uz trim gadiem (atbrīvots pirms termiña). ${ }^{63}$ N. L̦evindanto pakḷāīigums radīja spriedzi baptistu vidē. ${ }^{64}$ Pilnvarotā materiāliem par viņu pievienots anonīms dzejolis, kurā teikts, ka "jebkurš ateists ir taisnīgāks par tevi" un "tava miesa jau raugās kapā" cilvēka domas. Tã uz tevi skatās ne tikai Latvija, bet arī Igaunija un Lietuva. Pacieš tevi kā varas pārstāvi un tāpēc baidās tev teikt acīs patiesību. Neviens neuzskata tevi par ticīgu." ${ }^{\prime 66}$ G. Tūra atskaitēs par ceḷojumu uz Lielbritāniju baptisti kā delegācijas locekḷı pieminēti tikai garāmejot, kas liecina par arhibīskapa ekumeniskajām prioritātēm. Tās redzamas arī citos dokumentos - Tūrs, atskaitē pilnvarotajam uzskaitot baznīcas PSRS, ar kurām viņam veidojušās draudzīgas attiecības, pieminēja tikai luterāņu baznīcas Lietuvā un Igaunijā, kā arī KPB un pareizticīgo baznīcas Armēnijā un Gruzijā. ${ }^{67}$

Par delegācijas vizīti rakstijja Maskavā iznākošais Vissavienības Evaņgeēlisko kristiešu-baptistu savienības padomes (VEKBSP) žurnāls "Bratskij Vestnik". Tajā netrūka propagandisku skaidrojumu par britu religíiskās dzīves atšķirībām no PSRS notiekošā. Piemēram, teikts, ja Anglijā baznīcas sociālais darbs un tieši ar reliǵiju nesaistītas draudžu aktivitātes ir pašsaprotamas, tad PSRS "tas būtu lieki, jo visu šo darbu veic

62 RKLP Latvijas PSR pilnvarotais P. Liepa, KPBLP pilnvarotais Latvijas PSR A. Saharovs. Izziña par reliğisko organizāciju darbību Latvijas PSR uz 1962. gada 1. septembri. [krievu val.], 01.09.1962., LNA-LVA, 1448-1-180, 129.

63 N. L̦evindanto autobiogrāfija [krievu val.], 13.06.1952., LNA-LVA, 1419-2-12, 168.

64 1962. gadā mācītāju sanāksmē, kurā N. L̦evindanto ziņoja par VEKBP pieņemtiem valsts varas uzspiestiem jauniem ierobežojumiem draudžu darbībā, "daži prezbiteri (...) bija noskaņoti agresīvi”. Pirms sanāksmes opozīcijas pārstāvji mācītāji Pēteris Egle, Jona Inkenass un Pauls Pelčers iesniedza virkni, viņuprāt, sanāksmē aplūkojamu problēmjautājumu. Tos N. L̦evindanto pirms savas uzstāšanās sanāksmē pārrunāja ar pilnvaroto, un, kā teikts ziņojumā, "nekāda to apspriešana netika piel̦auta”. RKLP pilnvarotais P. Liepa, ziņojums RKLP priekšsēdētājam A. Puzinam, Latvijas KP CK sekretāram A. Vosam, Latvijas PSR MP priekšsēdētāja vietniekam V. Krūmiņam. [krievu val.], 30.12.1962., LNA-LVA, 1448-1-262, 70-72.

65 Veltijums personiski Jums, N. A. [krievu val.] LNA-LVA, 1419-2-12, 169. (bez datuma)

66 Ibid., 170.

67 G. Tūrs, Ko Evañgéeliski luteriskā baznīca Latvijas PSR ir darījusi, lai veicinātu mieru visā pasaulē un tautu draudzību un kādi tai bijuši kontakti ar ārzemju kristīgajām baznīcām [krievu val.], 09.02.1959., LNA-LVA, 1448-1-11, 32. 
arodbiedrības, strādnieku klubi u. c.”. Protams, tika uzsvērts, ka Padomju Savienībā valda relig̣ijas brīvība. ${ }^{68}$ Rakstā minēts, ka uz britu septītās dienas adventistu pārstāvja jautājumu par viņa ticības līdzgaitnieku stāvokli PSRS delegācijas locekḷi atbildējuši, ka "viņi brīvi pulcējas, tāpat kā citi ticīgie"69. Šādi izteikumi nesaskanēja ar tolaik izvērstajām represijām pret septītās dienas adventistu vadību - 1954. gada decembrī adventistu Vissavienības centra vadītājam Pāvelam Macānovam anulēja reǵistrācijas apliecību, pamatojot lēmumu ar to, ka viņš uztur kontaktus ar nereǵistrētām draudzēm, Maskavas draudzē notiek daudzas kristības un tiek atbalstītas represēto draudžu darbinieku ǵimenes. ${ }^{70}$ Dažus gadus vēlāk varasiestādes likvidēja centralizētas septītās dienas adventistu draudžu struktūras - vispirms PSRS līmenī un tad arī Latvijā. 1962. gadā RKLP un KPBLP pilnvarotie, ziņojot uz Maskavu, neslēpa gandarījumu par šo darbību rezultātiem - "sagatavoti un īstenoti septītās dienas adventistu centra likvidācijas pasākumi republikā. To rezultātā septītās dienas adventistu draudžu darbība Latvijas PSR lielā mērā tiks vājināta." ${ }^{11}$ RKLP pilnvarotais P. Liepa, gadu vēlāk ziņojot par Vissavienības centra pilnvarotā Latvijas PSR amata likvidēšanu, kancelejas slēgšanu un tās naudas līdzekļu konfiskāciju, konstatēja, ka tas "radījis nesaskaņas sektantu sludinātāju starpā”72.

\section{G. Tūra viesošanās recepcija latviešu diasporā}

Latviešu luterāṇu baznīca ārpus Latvijas (šajā rakstā lietotais saīsinājums LELBP apzīmē tās nosaukumu kopš 2020. gada - Latvijas Evañgêeliski luteriskā baznīca pasaulē) šajā rakstā aplūkotajā laika posmā uzskatīja sevi par vienīgo legitīmo pirms Otrā pasaules kara Latvijā eksistējušās luterāņu baznīcas turpinātāju un lietoja tās nosaukumu. Līdz ar to LELB pārstāvju vizītes ārzemēs un LELB iespējamo pievienošanos starptautiskām baznīcu organizācijām tā uztvēra negatīvi. Mācītāja Leona Čuibes brošūrā, kas angl̦u valodā sagatavota sakarā ar Pasaules baznīcu padomes dibināšanas asambleju 1948. gadā, G. Tūra amats likts pēdiņās un teikts, ka "vienīgā Latvijas luterāṇu baznīcas tiesību nesēja ir tās daļa, kas uz laiku ir spiesta uzturēties ārzemēs. Tā turpina pastāvēt, un to starptautiski atzīst visas brīvās luterāñu

68 J. I. Zidkov, “Pojezdka predstaviteljei VSJHB v Shotlandiju i Angliju”, Bratskij Vestnik 5 (1955), 19.

69 Ibid., 23.

70 Edgars Čerņevskis, Adventes kustība Latvijā (Rīga: Patmos, 1998), 42.

71 RKLP pilnvarotais Latvijas PSR P. Liepa, KPBLP pilnvarotais Latvijas PSR A. Saharovs. Izzinaa par reliǵisko organizāciju darbību Latvijas PSR teritorijā uz 1962. g. 1. septembri [krievu val.], 01.09.1962., LNA-LVA, 1448-1-180, 129.

72 P. Liepa, Atskaite par RKLP pie MP pilnvarotā Latvijas PSR darbu 1962. g. 19.02.1963. [krievu val.], LNA-LVA, 1448-1-262, 21. 
baznīcas pasaulē."’’33 Izceḷošanas sākumā bēglu negatīvā attieksme pret LELB bija saistīta ar to, ka viņi savu prombūtni uztvēra par īsu pagaidu stāvokli, kuram sekos atgriešanās dzimtenē un izceļojušās baznīcas vadības iepriekšējā statusa atjaunošana. ${ }^{74}$ Vēlāk tas saistîts ar aukstā kara pretstatijumiem.

"Londonas Avīze" ievietoja interviju ar G. Tūru, kurā parādās skaidrojums baznīcas marginālajai lomai PSRS un nelielajam dievkalpojumu apmeklētāju skaitam - "tie, kas tagad nāk baznīcā Latvijā, tie ir îstie Dieva meklētāji. Agrāk nāca, gaidot no Dieva kādus labumus, tagad baznīca nekā nevar dot, kā tikai Dieva vārdu..."’55 Diasporas presē bija pieminēts arī, ka G. Tūram bija līdzi Padomu Latvijā izdotās dziesmu grāmatas eksemplāri, kuriem vajadzēja kalpot par vienu no pierādijjumiem reliǵijas brīvībai PSRS. Taču vērīgi lasītāji pamanīja, ka luterāņu himna "Dievs Kungs ir mūsu stiprā pils" ir cenzēta, no tās izṇemot pantus, kuros runāts par to, ka velni neko nevarēs padarīt. ${ }^{76}$

Aprakstot PSRS baznīcu delegācijas vizīti, "Austrālijas Latvietis", rakstijja, ja LELB gribēs iestāties Pasaules luterānu federācijā (PLF), tad "var sagaidīt enerĝiskus pret solus no trimdas baltiešu luterānu rindām"77. Tajā pašā numurā ir arī LELBP arhibīskapa pārstāvja Austrālijā prāvesta Arnolda Grosbaha raksts, kurā kritizēta minētā vizīte. "Mēs, trimdas mācītāji un draudzes, saslējušies ap brīvās Latvijas ev. lut. baznīcas arhibīskapu Dr. T. Grīnbergu, nosodām melu propagandu, ko komunistu vara grib izplatīt, sūtīdama savu baznīcu delegāciju uz Angliju, un līdz ar mūsu baznīcas asinslieciniekiem apliecinām, ka Latvijā komunistu okupācijas vara min kājām visas cilvēka tiesības un to starpā arī reliǵisko brīvību." 78 Nosodošo attieksmi A. Grosbahs pamatoja ar to, ka baznīcas PSRS atrodas valsts kontrolē un ir spiestas kalpot padomju propagandas mērķiem, tāpēc to pārstāvji nav brīvi savos izteikumos. Latviešu presē līdzās anglikāņu baznīcas kritikai par delegācijas ielūgšanu bija arī atzinīgi vārdi par to, ka tā ir centusies nodrošināt, lai delegācija nebūtu pastāvīgā padomju vēstniecības uzraudzībā, un tāpēc izmitinājusi baznīcu pārstāvjus Lambetas pilī, kur viniem bija iespēja satikties individuāli ar interesentiem. ${ }^{79} \mathrm{G}$. Tūra un citu delegācijas locekḷ ignorēšanai ne visi piekrita - prāvests E. Bergs izteicās pret pilnīgu tikšanās noliegumu, un atzina, ka tikšanās

73 Leons Čuibe, The Lutheran Church of Latvia behind Iron Curtain (Stockholm: Latvian reporter in the Committee for Church activities among the Baltic peoples in Sweden, 1948), 31.

74 LELBP arhibīskaps Arnolds Lūsis atmiņās raksta par T. Grīnberga teikto kara beigās: "Mēs brauksim atpakal uz Latviju. Varbūt - jau vasarā." Arnolds Lūsis, Cilvēks bez mājām. Mācītājs bēg̣ı gaitās (Linkolna: LELBA apgāds, 1994), 117.

“Bezcerīgās sejas Latvijas dievnamos”, Londonas Avīze 477 (15.07.1955.), 1.

“Tursa dienas Anglijā”, Latvija Amerikā 58 (27.07.1955.), 1-2.

"Viesizrāde Londonā", Austrālijas Latvietis 294 (16.07.1955.), 1.

78 A. Grosbahs, "Patiesības aptumšošana”, Austrālijas Latvietis 294 (16.07.1955.), 1.

79 “Tursa dienas Anglijā”, Latvija Amerikā 58 (27.07.1955.), 1. 
ar G. Tūru bijusi būtiska informācijas apmaiņai. Vēl vairāk - "ignorējot viṇu, mēs būtu norobežojušies no dzimtenes draudzēm, kuru liktenis ir sevišķi grūts un kuras alkst pēc garīga stiprinājuma" ${ }^{\prime 0}$.

1956. gadā pēc ziņojuma par to, ka LELB meklē sakarus ar ārzemēm, noklausǐšanās, LELBP draudžu Lielbritānijā sinode pieņēma R. Mužika izstrādātu rezolūciju, kurā teikts, ka "sinode ir pateicīga ikvienam par pabalsta sniegšanu baznīcai okupētā Latvijā, bet kategoriski noraida tās patreizējās baznīcas vadības atzīšanu, jo tā nav ievēlēta saskaņā ar Latvijas Ev. lut. baznīcas 1928. gada satversmi”. ${ }^{81}$ E. Bergs sinodes vārdā 1957. gadā izsūtijja paziņojumu anglu valodā, kurā teikts, ka padomju sistēma pielieto jaunu metodi baznīcas prestiža mazināšanai - izmanto garīdzniekus propagandas mērķiem. Tâlāk viņš minēja, ka, lai gan oficiāli G. Tūrs un citi PSRS garīdznieku delegācijas dalībnieki bija Kenterberijas arhibīskapa viesi, "padomju valsts skatijumā vini bija "miera cīnītāji"”'s2. Diasporas pret miera kustību vērstā kritika sakrita ar britu varasiestāžu politiku - britu Ārlietu ministrijas Informācijas izpētes departamenta stratēgija bija nevis veidot alternatīvu miera kustību, bet censties parādīt esošo kā liekulīgu un PSRS finansētu. Šajā kampañā iesaistijās arī Anglijas baznīca - Jorkas arhibīskaps Kirils Garbits (Garbett) kritizēja miera kustību BBC radiopārraidēs. ${ }^{83}$

Interesantas un no daudziem citiem viedokl̦iem atšksirīgas bija vēlāk Latvijā pazīstamā filozofa Roberta Mūka pārdomas par situācijas divdabību - nav noliedzams, ka baznīca padomju režīmā dzīvo kompromisos ("Kristīgā baznīca, izvēlēdamās pastāvēšanu komunismā, pēdējam pakalpo un reizē kroplọ pati sevi, jo visā savā îstumā un lielumā tā nevarētu pastāvēt"), taču vienlaikus jājautā, cik ētiski ir latviešiem ārpus Latvijas uzdoties pamācītāju un kritiķu lomā, jo viņi ne ar ko neriskē. "Mūsu trimda nav tā, kurai būtu tiesības ieteikt moceklības ceļu dzimtenes baznīcai. Mēs esam ārpus īstās cīņas robežām. Mēs cīnāmies no klubkrēsliem un varam būt diezgan droši, ka šī cīṇa mums nemaksās galvas (gluži kā ir salona komunisti, ir arī salona antikomunisti)." ${ }^{\prime 4}$ Diasporas kristiešu morālās tiesības nosodīt dzimtenē palikušos - tā ir tēma, kas parādās arī citu etniskām grupām piederīgu intelektuālu izteikumos. No PSRS izsūtītais rakstnieks Aleksandrs Solžeņicins vēstulē Maskavas patriarhātu noliedzošās Krievu pareizticīgās

\footnotetext{
80 “Satikt G. Tursu bija vajadzīgs", Latvija 29 (06.08.1955.), 3.

81 Latvijas Evañgéliski luteriskās baznīcas Lielbritānijā sinode 25.-26.08.1956., LNA-LVA, 2303-11v-15, 39.

82 Prāvesta E. Berga paziņojums, [anglu val.] 06.02.1957., LNA-LVA, 2303-11-v-33, 25.

83 John Jenks, British Propaganda and News Media in the Cold War (Edinburgh: Edinburgh University Press, 2006), 118.

84 Roberts Mūks, "Medal̦as otra puse. Pārdomas sakarā ar kādu apmeklējumu no Rīgas Londonā", Latvija 32 (27.08.1955.), 4.
} 
baznīcas ārzemēs (KPBĀ) koncilam 1974. gadā, pieminot paša savulaik pausto patriarhāta nosodījumu, rakstijja, ka "pēc robežas škēersošanas viņš tiesības to atkārtot ir zaudējis" $" 5$.

Arhīvu lietas atklāj, ka diasporas organizācijas, ieskaitot LELBP, bija ieinteresētas neformālos kontaktos ar G. Tūru. Starp Anglijas baznīcas Ārlietu padomes dokumentiem ir ziñojums par tikšanos ar Kārli Zariņu, kurš teicis, ka T. Grīnbergs vēlas satikt G. Tūru. Ārlietu padomes pārstāvja (pēc paraksta spriežot, H. Vadamsa) atbilde bija, ka sūtīt oficiālu ielūgumu T. Grīnbergam nebūtu pareizi, jo padomju puse to uztvertu kā intrigas vērpšanu. Taču, ja viņš vizītes laikā pēc $K$. Zariṇa ielūguma būtu Londonā, tad Kenterberijas arhibīskaps sarīkotu neoficiālu abu arhibīskapu tikšanos. ${ }^{86}$ Šāda tikšanās nenotika, tomēr ir vērā ñemams fakts, ka par spīti noliedzošai retorikai LELBP vadība bija gatava uz šādu soli. Padomju okupācijas apstākḷıs G. Tūram nebija iespējams publiski pozitīvi izteikties par LELBP un tās vadību. Tomēr pēc T. Grīnberga nāves viņš 1962. gada 20. jūnijā dievkalpojumā Rīgas Lutera baznīcā pieminēja savu mirušo kolēgí, gan dēvējot viņu par savu priekšteci, bijušo arhibīskapu. ${ }^{87}$

Kenterberijas arhibīskapa rīkotā pieņemšanā par godu padomju garīdznieku delegācijai piedalijās arī diasporas latvieši - LELBP arhibīskapa vietnieks Edgars Bergs, neatkarīgās Latvijas Republikas sūtnis Lielbritānijā Kārlis Zariņš (vēlāk skaidrojot, ka pārstāv Britu un ārzemju Bībeles biedrību), mācītājs Ringolds Mužiks. Kenterberijas arhibīskaps pieņemšanā sacītā runā minēja gan pirmskara sarunas starp Baltijas un Anglijas baznīcu pārstāvjiem, gan to, ka Anglijas baznīca palīdz Baltijas baznīcu locekliiem, kuri šobrīd dzīvo Anglijā. ${ }^{88}$ Līdz ar to netieši tika pieminēta arī diaspora. Interesanti, ka arhibīskaps no PSRS atbraukušos garīdzniekus uzrunāja kā "krievu un Baltijas republiku delegāciju" (Delegation of Christians from Russian and the Baltic republics). ${ }^{89}$ K. Zarinš̌ nosūtija britu Ārlietu ministrijai pēc tās ierēdņa Ėrla Dželiko (Earl Jellicoe) lūguma slepenu vēstuli, kurā sīki informēja par sarunu ar Tūru. Viņš esot daudz stāstījis par grūto sadzīvi Latvijā un baznīcas grūto stāvokli. R. Mužiks viņam piedāvājis palikt Lielbritānijā. Atbilde neesot bijusi noraidoša, taču Tūrs teicis, ka patlaban viņa vieta ir

85 Dmitrij Pospelovskij, Russkaja pravoslavnaja cerkovj v XX veke (Moskva: Respublika, 1995), 237.

86 Memorandum. Visit of Russian Delegation to England, 12.05.1955., Lambeth Palace Library, CFR LRC 95/1, Latvia: Contacts: Archbishop Turs, 10.01.1955.-20.03.1973., 6.

87 LELB baznīcas virsvaldes plenārsēžu protokoli (27.01.1960.-17.10.1989.), LELB arhīvs, 1-3-42, Protokols Nr. 11, 15.11.1962., 43op.

88 Nikaean Club. Lambeth Palace Reception for Delegation of Christians from U.S.S.R. Sermon by the Archbishop of Canterbury, 11.07.1955., Lambeth Palace Library, CFR LRC 95/1, Latvia: Contacts: Archbishop Turs, 10.01.1955.-20.03.1973., 11.

89 Ibid., 10. 
dzimtenē, kā arī atzīmējis, ka vecums neļauj viņam nostāties pret padomju režīmu un beigt dzīvi koncentrācijas nometnē. ${ }^{90}$

Attieksmē pret PSRS garīdznieku delegāciju parādijīàs arī diasporas latviešu no Latvijas līdzi paņemto atšķirīgo politisko uzskatu radītā spriedze, kurā Tūra vizītes atspoguḷojums kalpoja kā līdzeklis oponentu noliegšanai. Piemēram, latviešu sociāldemokrātu izdevums "Brīiība" rakstīja: "Visa šĩ raibā tursiāde Londonā rāda, ka daudzi labā spārna vīri zaudē visu savu pretkomunismu, tikko viņi saduras ar bijušo "savu cilvēku": kā zināms, Turss ir bij. Zemnieku savienības darbinieks, korporelis un karsts Ulmaña diktatūras piekritējs." ${ }^{91}$

Kontakti starp LELB un G. Tūrs ziņojumā baznīcas virsvaldes prezidijam par vizīti Anglijas baznīcu pēc 1955. gada vizìtes Anglijā tikšanos ar latviešiem nepieminēja, toties stāstijja, ka sañēmis daudz dāvanu - grāmatas, albumus, bet tās nav varējis atvest un nodevis PSRS sūtniecībai Londonā nogādāšanai uz dzimteni caur Maskavas patriarhātu..$^{92}$ Tolaik tas bija viens no retajiem veidiem, kā ievest reliǵisko literatūru. To bija aț̣auts ievest ar īpašām aț̣aujām, tika konfiscētas arī no Austrumu bloka valstīm sūtītas reliǵiskas grāmatas. ${ }^{93} \mathrm{Ne}$ vienmēr G. Tūram sūtītās grāmatas viņu sasniedza, un kādā gadījumā G. Tūrs arī uzstāja, lai tiktu ievērots RKLP teiktais, ka sešiem baznīcu vadītājiem PSRS aț̣auts saņemt teologiisko literatūru personīgi, bez īpašas pārbaudes. ${ }^{94}$

Pēc vizìtes LELB un Anglijas baznīcas vadība regulāri baznīcas svētkos apmainijās ar apsveikumiem. G. Tūrs pēc ceḷojuma uz Lielbritāniju saņēma no Britu baznīcu padomes piemiņas albumu ar fotogrāfijām un avižu izgriezumiem par viņa vizīiti. Tas tika nodots caur padomju vēstniecību Londonā, un G. Tūram to tālāk nosūtỉja RKLP. ${ }^{95} \mathrm{Uz}$

90 Antonijs Zunda, Inesis Feldmanis, Latvijas ārpolitika un diplomātija 20. gadsimtā, 2. sēj. Baltijas jautājums 1940-1988 (Rīga: Jumava [2015-2016]), 117-118.

91 "Tursiāde Londonā", Brīvība 7 (01.08.1955.), 6.

92 LPSR Ev. lut. baznīcas virsvaldes prezidija protokoli (15.02.1952.-25.11.1959.), LELB arhīvs, 1-3-46, protokols Nr. 31, 23.08.1955., 92op-93.

93 1961. gadā sastādītā sarakstā ar konfiscētām bandrolēm ir no VDR sūtīti katkiismi latviešu valodā, Brālu draudzes lozungu (ikdienas lasījumu) grāmata un citi VDR kristīgo konfesiju izdevumi. “Latvijas PSR "Glavlitita” politcenzores Pel̦evinas 1961. gada 17. maija saraksts par Rīgas pastā desmit dienu laikā konfiscētajām bandrolēm ar literatūru, kas ienākušas no tautas demokrātijas zemēm," Latvijas Okupācijas muzeja gadagrāmata 2001. Nācija gūstā (Rīga: Latvijas 50 gadu okupācijas muzeja fonds, 2002), 203-204.

94 G. Tūra vēstule P. Liepam, 20.10.1962., LNA-LVA, 1448-1-160, 117.

95 RKLP priekšsēdētāja I. Poḷanska vēstule RKLP pilnvarotajam J. Restbergam. [krievu val.] 24.11.1955., LNA-LVA, 1448-1-7, 108. 
Kenterberijas arhibīskapa teikto G. Tūrs atsaucās kārtējā miera aicinājumā protestantiskajām baznīcām 1959. gadā: "Neviens kristietis nevarētu ienest labākus priekšlikumus kā tos, ko ienesis N̦. S. Hruščovs Apvienoto Nāciju Organizācijas G̦enerālajā asamblejā." 96 Citos gadījumos, kad Anglijas baznīcas vadības izteikumi par PSRS bija negatīvi, padomju varas iestādes no G. Tūra prasija kritikas paušanu. Interesanti, ka G. Tūrs vairījās no tā, tādējādi parādot, ka viņa amats un starptautiskā atpazīstamība sniedz viņam kaut nelielu rīcības brīvību. Kā teikts vienā no RKLP pilnvarotā ziņojumiem, G. Tūrs atteicies nosodīt "Kenterberijas arhibīskapa Fišera agresīvos pretpadomju izteikumus". Tādējādi viņš pilnvarotā skatījumā parādīja, ka "ir nenoturīgs miera cīnītājs"97.

1955. gada vizīte, lai gan tika izmantota padomju propagandas mērḳiem, bija nozīmīga tālāku kontaktu veidošanā - tās laikā G. Tūrs un Igaunijas Evaņgêeliski luteriskās baznīcas arhibīskaps Jans Kīvits (Kiivit) Lambetas pilī tikās ar PLF generālsekretāru Karlu Lundu-Kvistu (Lund-Quist), kā vēlāk salīdzināja sarunas abiem baznīcu vadītājiem (sarunas organizēja un protokolēja igauņu mācītājs Jāks Tauls (Taul)) - Kīvits viņam likās cilvēciskāks un pieejamāks, viņš esot izvairījies no PSRS ekonomiskās un politiskās situācijas raksturošanas. Tūrs vairāk runājis vispārīgi par karu un mieru. Tomēr abi snieguši informāciju par draudžu dzīves aizkulisēm - cilvēki atgriežas no izsūtījuma, starp tiem arī mācītāji, kas atkal sāk kalpot draudzēs. Viņi neslēpa, ka ir problēmas iegūt teologiisko izglītību un izdot religisko literatūru, trūkst mācītāju, lauku draudzēm ir īpaši grūti. ${ }^{98}$ Redzams, ka tolaik PLF jau bija sākusi izskatīt iespēju veidot ciešākas attiecības ar luterāṇu baznīcām PSRS un tās satelītvalstīs. Savukārt baznīcām diasporā K. Lunds-Kvists tajā pašā 1955. gadā sanāksmē Vācijā apliecināja, ka PLF saredz viņu īpašo lomu. "Jums nevienam nav jābaidās no tā, ka tagadējās baznīcas Baltijas valstīs Igaunijā, Latvijā un Lietuvā, un šo baznīcu tur no boļševikiem ieceltie vadītāji tiktu no PLF [tekstā lietots angliskais saīsinājums LWF - V. T.] atzīti." ${ }^{99}$ Kā zināms, notika citādi 1963. gadā LELB uzñēma PLF.

96 "Latvijas Evangéēliski luteriskās baznīcas virsvaldes aicinājums protestantisko baznīcu vienībām un to pārstāvjiem", Ev. lut. baznīcas kalendārs 1960. gadam (Rīga: [b. i., b. g.]), 39. G. Tūrs atsaucās uz arhibīskapa Dž. Fišera 1959. gadā teikto Britu baznīcu padomes Ārlietu nodaļas sanāksmē, kurā viņš pauda izbrīnu, ka Lielbritānijas valdība nav reageejusi uz N̦. Hruščova aicinājumu pilnībā atbruņoties. Fišers teica, ka cilvēki par to ir gadiem lūguši Dievu un ka N̦. Hruščovs "nevarētu vēl prasmīgāk lasīt Jauno Derību", kā viņš jau ir darījis. Trevor Beeson, Priests and Politics: The Church Speaks Out (London: SCM Press, 2013), 137.

97 RKLP pilnvarotā J. Restberga informatīvā atskaite par RKLP pilnvarotā Latvijas PSR darbu 1955. g. pirmajā pusē [krievu val.], 19.01.1956., 1448-1-254, 156.

98 Riho Altnurme, "Foreign Relations of the Estonian Evangelical Lutheran Church as a Means of Maintaining Contact With the Western World”, Kirchliche Zeitgeschichte 19:1 (2006), 163.

99 Elmārs Rozītis, "Atskats par Latvijas Ev. lut. baznīcas darbu Virtembergā-Bādenē un Pfalcā", Latvijas Ev. lut. baznīcas kalendārs 1956. gadam (Latvijas Ev. lut. baznīcas virsvaldes izdevums, [b. g., b. v.], 94. 
Citos ziņojumos Rietumu baznīcu pārstāvji izteica skepsi arī par J. Kīvitu - Lambetas pils arhīvā ir 1959. gadā rakstīts ziņojums par telefona sarunu ar Anglijā dzīvojošo latviešu luterāņu mācītāju R. Mužiku, kas Minhenē saticis J. Kīvitu, kurš viņam teicis, ka "baznīcas dzīves situācija Latvijā nav tik dramatiska, jo Doma katedrāle vēl aizvien ir baznīcas pārvaldīšanā un tajā tikai pa retam notiek koncerti”. R. Mužiks no citiem informācijas avotiem zināja, ka G. Tūrs devies uz Maskavu, lai iestātos par katedrāles saglabāšanu dievkalpojumiem un ka garīdzniekus padomju vara soda par dievkalpojumu noturēšanu kapos, jo tādējādi tie atturot cilvēkus no ražas novākšanas. ${ }^{100}$ Jāñem arī vērā, ka LELB sākumā cerēja, ka katedrāli izdosies dal̦ēji saglabāt dievkalpojumiem vai atgūt pilnībā - "kad baznīca būs izremontēta, tad atkal varēs pacelt jautājumu par tās atdošanu draudzei" ${ }^{101}$. Baznīcas virsvalde mēgeināja panākt, ka reizi mēnesī arhibīskaps varētu tur noturēt dievkalpojumu, argumentējot, ka "caur to tiktu mazināta pretpadomju aǵitācija ārzemēs". ${ }^{102}$ Tādējādi LELB vadība centās veidot vārdisku saspēli ar padomu ārpolitikai jūtīgiem jautājumiem. Šoreiz gan nesekmīgi.

Par baznīcas dzīvi PSRS daudz pasaka ne tikai vizītes laikā teiktais, bet arī tas, kas Latvijā notika G. Tūra prombūtnē. Pilnvarotā arhīva lietas rāda, ka viņa tuvākie līdzstrādnieki ziņoja par viņu. Pilnvaroto apmeklēja prāvests Pēteris Kleperis, kas stāstīja par to, ka pirms brauciena Tūrs sarunājies dzīvoklī ar Kleperim nezināmiem cilvēkiem, kā arī ka arhibīskaps centies dabūt brauciena vajadzībām ārzemju valūtu. P. Kleperis arī redzējis G. Tūram adresētu vēstuli no Austrālijas. ${ }^{103}$ P. Kleperis apmeklēja pilnvaroto arī vēlāk un ziņoja par Tūra plāniem apmeklēt Jelgavas Annas baznīcu kopā ar vīru kori, uz ko pilnvarotais reageēja, sakot, ka kora izbraucieni "nav vēlami”"104. Pilnvarotais neatbalstīja kora darbību, sakot, ka "kori, kurā ir aptuveni 40-45 cilvēki, veido raibs pūlis - tur ir gan sektanti, gan pareizticīgie”. Turpat arī pausts viedoklis, ka korim nav jālauj braukāt pa draudzēm, jo tas izraisa negatīvu vietējo varasiestāžu reakciju, un citi kori gribēs darīt tāpat. Draudzēm arī esot iebildumi pret kora uzṇemšanas finansiāliem izdevumiem. ${ }^{105}$

100 For the files, 09.10.1959., Lambeth Palace Library, CFR LRC 95/1, Latvia: Contacts: Archbishop Turs, 10.01.1955.-20.03.1973., 51. (sastādītāja uzvārds nav atšifrēts, bet iniciāli liecina, ka autors ir Dž. Satersveits).

101 Protokols Nr. 51, 08.05.1959., LELB arhīvs, Latvijas PSR Ev. lut. baznīcas virsvaldes plenārsēžu protokoli (24.01.1952.-16.11.1959.), 179.

102 Ibid., 179op.

103 RKLP pilnvarotā sarunu ar apmeklētājiem pieraksts [krievu val.], 01.07.1955., LNA-LVA, 1448-1254, 83.

104 Ibid., 84.

105 Pilnvarotā J. Restberga vēstule Religijas kultu lietu padomes priekšsēdētājam I. Poḷanskim [krievu val.] 23.09.1955., LNA-LVA, 1448-1-7, 80. 
Atgriezies Latvijā, G. Tūrs izmantoja notikušo vizīti, lai rīkotu īpašus dievkalpojumus un tādējādi aktivizētu reliǵisko dzīvi. Pateicības vēstulē Kenterberijas arhibīskapam Dž. Fišeram G. Tūrs raksta, ka pēc atgriešanās Latvijā noturējis dievkalpojumu Rīgas Domā, kurā aizlūdzis par britu karalieni, valdību un nāciju, kā arī plāno līdzīgu dievkalpojumu Anglikāņu baznīcā. ${ }^{106}$ "Church Times" ziņoja, ka G. Tūrs Maskavas radio angliski raidītā pārraidē teicis, ka aizlūgs par britiem atjaunotajā Anglikāņu baznīcas ēkā Rīgā. ${ }^{107}$ Baznīcas kalendārā 1956. gadam ievietota fotogrāfija ar parakstu "Miera izlūgšanas dievkalpojums Anglikāņu baznīcā Rīgā 1955. gada 14. augustā pēc arhibīskapa atgriešanās no Lielbritānijas" ${ }^{\prime 108}$. Tolaik Anglikāṇu baznīcu dievkalpojumiem izmantoja Sv. Pētera ev. lut. draudze. Bijušā anglikāņu dievnama fotogrāfija baznīcas iespiedizdevumos, lielu pasākumu rīkošana, iespējams, bija veids, kā censties to saglabāt dievkalpojumiem. Draudze bija neliela, un tai bija grūtības nomaksāt nodokḷus un citus maksājumus. ${ }^{109}$ Daļa draudzes locekḷu bija aizgājuši līdzi mācītājam Jānim Liepiņam uz Doma draudzi. Draudze cerēja, ka tās darbību atdzīvinās tolaik populārais piētiski orientētais mācītājs Haralds Kalniņš, bet viņu ievēlēja Jēzus ev. lut. draudze. ${ }^{110} \mathrm{G}$. Tūrs ar Jāņa Nameiša Vēja starpniecību nodeva Anglijas baznīcai informāciju par anglikāņu baznīcas Rīgā vēsturi un pašreizējo stāvokli - tekstā minēts, ka draudze pēdējos gados veikusi nozīmīgus remontus: 1952. un 1953. gadā - izveidoti jauni griesti, 1956. gadā - atjaunota mūra sēta ap baznīcu, 1958. gadā - atvērta pagraba zāle dievkalpojumiem ziemas laikā, izbūvēta ērgelęu lukta korim. ${ }^{111}$ Anglikāṇu baznīcas Rīgā liktenis ir arī citu Lambetas pils arhīva dokumentu satura tēma. Kenterberijas arhibīskapa vēstulē G. Tūram izteikta pateicība, ka anglikāṇu dievnamu draudze to uztur labā stāvoklī un ka draudze būtu gatava atdot dievnamu izmantošanai anglikāņu draudzei, ja tāda būtu. Tam gan seko piebilde, "kas

106 Gustavs Tūrs, Letter to G. Fisher, 05.08.1955., Lambeth Palace Library, CFR LRC 95/1, Latvia: Contacts: Archbishop Turs, 10.01.1955.-20.03.1973., 22.

107 “Riga's Archbishop Praises Eton”, Church Times CXXXVIII: 4826 (05.08.1955.), 11.

108 Latvijas Evangóēliskās luteriskās baznīcas kalendārs 1956. gadam (Rīga: [b. i., b. g.]), 42.

109 Anglikāñu baznīcu dievkalpojumiem slēdza 1966. gadā. Sv. Pētera ev. lut. draudze pievienojās Lutera draudzei. Pēdējais dievkalpojums Anglikāņu baznīcā notika 1965. gada beigās. Pirms tam draudze vairākkārt nesekmīgi mēgeināja atrast loceklus likumā obligātajam "divdesmitniekam" (draudzes garantiem), dievkalpojumi notika neregulāri. RKLP Latvijas PSR pilnvarotais P. Liepa. Slēdziens par sv. Pētera reliǵiskās draudzes noṇemšanu no reǵistrācijas un lūgšanu ēkas, kas atrodas Rīgas pils., Komjaunatnes krastmalā 7 slēgšanu [krievu val.], LNA-LVA, 1419-1-6, 86.

110 LELB baznīcas virsvaldes plenārsēžu protokoli (27.01.1960.-17.10.1989.), LELB arhīvs, 1-3-42, Protokols Nr. 17, 20.04.1965., 71op; Ibid., Protokols Nr, 20, 30.09.1965., 80.; Ibid., Protokols Nr. 22, 24.01.1966., 85op.

111 Message received from Archbishop Turs' office in Riga (brought by Mr. Janis Vejs), 20.09.1959., Lambeth Palace Library, CFR LRC 95/1, Latvia: Contacts: Archbishop Turs, 10.01.1955.20.03.1973., 52. 
gan var pateikt, kad tas notiks”"112. Dž. Fišers dāvanā no G. Tūra bija sañēmis albumu, kurā bija arī Anglikāņu baznīcas fotogrāfijas, un ieinteresējies par to. Viņa vēstulei G. Tūram arhīva lietā seko neparakstīts dokuments, kura autors, iespējams, ir pats Tūrs. Tajā teikts, ka dievkalpojumi baznīcā notiek svētdienās un trešdienās, 1959. gada 20. septembrī tiks svinēta dievnama simtgadu jubileja, kā arī beigās ievietota standarta frāze, ka "katrā dievkalpojumā mēs lūdzam par mieru visā pasaulē"113. Sešdesmitajos gados kāds cel̦otājs, kas bija no ārpuses apskatījis baznīcu, rakstijja, ka tā izskatās diezgan nolaista un kāds Rīgas iedzīvotājs teicis viņam, ka luterāṇu draudze pārtraukusi tur noturēt dievkalpojumus. ${ }^{114}$ Somijas luterāņu arhibīskaps Marti Simojoki (Simojoki) sniedza optimistiskāku informāciju - vinş̌ bija apmeklējis Anglikāņu baznīcu, viesojoties Rīgā gandrīz tajā pašā laikā (1964. gada sākumā) - tajā katru svētdienu notiekot divi dievkalpojumi, uz baznīcas kāpnēm vingu sagaidījis un anglu valodā uzrunājis vīrietis, kas turējis rokā zizli, kas atgādina anglikāņu draudžu aizgādņu lietoto. ${ }^{115}$ Kad kḷuva zināms, ka baznīcu vairs dievkalpojumiem neizmanto, prāv. R. Mužiks ieteica Anglijas baznīcai prasīt no PSRS kompensāciju, taču ieteikums bija novēlots, jo kompensācijai par britu zaudējumiem Baltijas valstīs pieteikties varēja līdz 1969. gada decembrim. ${ }^{116}$ Britu varasiestādes bija piesardzīgas šajā jautājumā, sakot, ka, pat ja pieteikums būtu iesniegts laikus, nebūtu garantijas, ka kompensāciju izdotos saņemt un ka britu vēstniecība Maskavā neuzskatot, ka lietas uzsākšanai ir "labvēlīgs laiks". ${ }^{117}$

Sakaru ar Anglijas baznīcu rezultātā LELB pavērās iespējas sūtīt teoloğijas studentus uz Lielbritāniju. Tas tolaik bija jauns pavērsiens, kuru tāpēc vērts analizēt sīkāk. 20. gadsimta piecdesmitajos gados tā bija reta iespēja - neskaitot igauņu un latviešu luterāņus, pāris reižu musulmaņiem bija ļauts sūtīt studentus uz Ėğipti, baptistiem - uz Lielbritāniju. ${ }^{118}$ 1956. gadā G. Tūrs saņēma Anglijas baznīcas vēstuli, kurā bija izteikts aicinājums sūtìt studēt teoloǵiju vienu studentu. Studijām baznīcas virsvalde virzīja vairākus kandidātus, no kuriem beigās palika vēlākais arhibīskaps Jānis Matulis un

112 G. Fisher, Letter to G. Turs, 16.07.1956., Lambeth Palace Library, CFR LRC 93, Latvia: General Situation, 20.03.1944.-07.10.1976., 76.

113 Ibid., 77. (Dokumentam nav nosaukuma un datuma)

114 T. Garrett, The Anglican Church in Riga, 25.02.1964., Ibid., 92.

115 M. Simojoki, Letter to J. Satterthwaite, 26.03.1964., Ibid., 94. Aizgādnis / pilnvarotā persona (churchwarden) - draudzes amatpersona anglikānismā (kopš 13. gadsimta), ekvivalents draudzes priekšniekam luterānismā, taču Anglijas baznīcas draudzēs ir divi aizgādņi.

116 Michael Moore, Letter to Ringolds Mužiks, 14.12.1970., ibid., 106.

117 Alexander Morlay, Claims Department, Letter to the Bishop of Fulham, 15.03.1971., ibid., 112.

118 Nikita Pivovarov, "What Kind of Religious Persons Were Invited to the USSR, and Who Was Allowed to Go Abroad (1943-1985)", State, Religion and Church 4:2 (2017), 103-104. https://pdfs.semanticscholar.org/213b/5bd55a2742e2e970ad744b1da35bddddb200.pdf? ga=2.224093151.592533201.1597945592-641591829.1597945592 (skatīts 19.08.2020.) 
vēlāk pazīstamais filozofs J. Vējš. ${ }^{119}$ Par to baznīcas virsvaldes 1959. gada 10. jūnija sēdes protokolā ir ieraksts, ka "Valdība [lielais sākuma burts tekstā - V. T.] ${ }^{120}$ piekritusi, ka uz Angliju var sūtīt Teologisko kursu kursantu Vēju”"121. Viņš bija vienīgais kandidāts, kas pirms tam nebija saistīts ar baznīcu. Kā vinš pats atceras (spriežot pēc Z. Mankusas pierakstītām atmiņām), piedāvājumu studēt viņš saņēmis no prāvesta P. Klepera, kas bija viņa tēva korporācijas biedrs. Apmēram gadu J. Vējš apmeklēja Teologiiskos kursus Rīgā. ${ }^{122}$ lespēja studēt ārzemēs LELB bija tik īpaša, ka šis fakts tika iezīmēts ar ritualizētām darbībām - 1959. gada 30. septembrī viņš parakstīja solījumu baznīcas virsvaldei, ka "centīsies ar savām čaklām studijām un krietnu uzvešanos attaisnot Latvijas evangêēeliski luteriskās baznīcas dāvāto uzticību un iegūtās teoloǵiskās zināšanas izlietos mūsu baznīcas labā"123. Tā bija tam laikam unikāla iespēja mācīties pie pasaulslavenām autoritātēm - J. Vējš atceras, piemēram, baznīcas vēsturnieka Džona Kelija (Kelly) lekcijas. Kāpēc padomju vara piel̦āva šādas studijas, viņam nav atbildes. lespējams, tas ir "gan jau noderēs" faktors, kā arī tolaik PSRS akcentētās ideoloǵiskās cīṇas dẹḷ. Varbūt tā bija vēlme ne tik daudz pētīt ārzemju akadēmisko vidi, kā nodrošināties ar cilvēkiem, kas nākotnē uzmanītu par britu valodu un kultūru interesējošos cilvēkus Padomju Latvijā. No vienas puses, attīstīt ang! u valodas un literatūras studijas, no otras - uzmanīt šo procesu. ${ }^{124} \mathrm{~J}$. Vēja studijas sakrita ar laiku, kad PSRS intensificēja sakarus ar ārvalstīm ar draudzības biedrību starpniecību, izmantojot tās kā "maigās varas" instrumentu. Formāli tās bija sabiedriskas organizācijas, bet faktiski bija valsts un partijas iestāžu veidotas struktūras. ${ }^{125}$ Šìm struktūrām vajadzēja kvalificētus cilvēkus.

119 Latvijas PSR Ev. lut. baznīcas virsvaldes plenārsēžu protokoli (24.01.1952.-16.11.1959.), LELB arhīvs, 1-3-41, Protokols Nr. 50, 16.03.1959., 170. J. Vējš stāsta, ka vinš Oksfordā dzīvojis Viklifa koledžā (Wycliffe Hall), bet bakalaura grādu (B. A.) grādu ieguvis Svētās Katrīnas koledžā (līdz 1962. gadam tās nosaukums bija Svētās Katrīnas biedrība (St. Catherine's Society)) - tā deva iespēju iegūt Oksfordas Universitātes grādu, nedzīvojot uz vietas šīs universitātes koledžās un tādējādi samazinot izmaksas. Valda Tēraudkalna saruna ar Jāni Nameisi Vēju Jūrmalā, 2019. gada 26. novembrī.

120 Tā laika presē lielo sākuma burtu lietojums vārdkopā "padomju valdība" un vārdā "valdība" bija dažāds pat vienā tekstā - sk., piemēram, "PSRS valdības protesta nota Pakistānas valdībai", Cina 115 (15.05.1960.), 3.

121 Latvijas PSR Ev. lut. baznīcas virsvaldes plenārsēžu protokoli (24.01.1952.-16.11.1959.), LELB arhīvs, 1-3-41, Protokols Nr. 52, 10.06.1959., 185.

122 Zanda Mankusa, "Latvijas Evaņgêeliski-luteriskās baznīcas mācītāju darbība laika posmā no 1954. līdz 1964. gadam”, Celšš 53 (2001), 62-63.

123 LPSR Ev. lut. baznīcas virsvaldes prezidija protokoli (15.02.1952.-25.11.1959.), LELB arhīvs, 1-3-46, Protokols Nr. 73, 30.09.1959., 218.

124 Valda Tēraudkalna saruna ar Jāni Nameisi Vēju Jūrmalā 2020. gada 31. jūlijā.

125 Šāda biedrība ar nosaukumu "Latvijas un ārzemju kultūras sakaru biedrība" 1956. gadā tika dibināta arī Latvijā. Lai biedrība ārēji izskatītos prestiža, par tās valdes priekšsēdētāju virzīja 
Kopā ar J. Vēju studēja igaunis Kaide Rātseps (Rätsep). ${ }^{126}$ Kad pēc viña nāves (1994. g.) kļuva pieejami agrāk slepenie arhīvi, atklājās, ka viņš bijis VDK agents. ${ }^{127}$ Vienlaikus ar abiem studentiem no PSRS teoloǵiju Oksfordā studēja Maikls Bordo (Bourdeaux), kas vēlāk daudz darīja, lai dokumentētu religisko dzīvi PSRS un pievērstu Rietumu sabiedrības uzmanību ticīgo vajāšanām. Savās atmiṇās viņš atceras J. Vēju kā tā laika draugu. ${ }^{128}$

G. Tūrs vēlāk sarunā ar Džonu Satersveitu (Satterthwaite) ${ }^{129}$ stāstīja, ka viņam bijusi nesaprašanās ar J. Vēju, kas pēc atgriešanās vēlējies tikt ordinēts, taču arhibīskaps bijis gatavs to darīt tikai pēc kandidāta gada, un ar to viņu cel̦i šķīrušies. ${ }^{130} \mathrm{~J}$. Vējš vēlāk pēc atgriešanās aizstāvēja disertāciju par anglikānismu un publicēja grāmatu par šo tēmu. Ar to saistīta interesanta to laiku raksturojoša epizode - tā kā, pēc grāmatas redaktores

Latvijas PSR Zinātṇu akadēmijas locekli Pēteri Valeskalnu. "Nodibināta Latvijas biedrība kultūras sakaru uzturēšanai ar ārzemēm”, Cīnna 24 (28.01.1956.), 1. Zīmīgi, ka biedrības atbildīgais sekretārs bija Leonīds Rimjans, kas vēlāk bija PSRS vēstniecības atašejs Stokholmā. Viņš izplatija Padomju Latvijas grāmatas, žurnālus un filmas, veidoja kontaktus ar latviešu kultūras darbiniekiem, cenšoties pierunāt viņus atgriezties Latvijā. Vēlāk viņš klıuva par Latvijas komitejas kultūras sakariem ar tautiešiem ārzemēs prezidija priekšsēdētāju. Eva Eglāja-Kristsone, Dzelzsgriezēji: Latvijas un Rietumu trimdas rakstnieku kontakti (Rīga: LU Literatūras, folkloras un mākslas institūts, 2016), 35-39. P. Valeskalns bija padomju funkcionārs, kas 1940. gadā bija atsūtīts uz Latviju, lai vadītu izglìtības sistēmas sovjetizāciju. Viņ̌̌ tika iekļauts Augusta Kirhenšteina vadītajā valdībā. Jānis Stradinš̌, "Totalitārie okupācijas režīmi pret Latvijas zinātni un akadēmiskajām aprindām (1940-1945)”, http://lpra.vip.lv/stradins.htm (skatīts 06.08.2020.)

K. Rātseps 1961. gadā Oksfordā ieguva Baccalaureus Litterarum (B. Litt.) grādu, kas uzskatāms par mag̣istra grāda ekvivalentu. legūtā izglìīība viņam deva iespēju pasniegt luterāņu Teologijas institūtā Tallinā. Viņš rakstijja rakstus par Jaunās Derības apokrifiem kopā ar slaveno igauņu teologu Uku Masingu (Masing). Riho Altnurme, "Theology in Soviet Estonia: Academic degrees and publications", Timo Kapanen, Timo, Nico Lamminparras, ed., Aatteiden ja herätysten virrassa. Jouko Talosen juhlakirja (Helsinki: Suomen kirkkohistoriallinen seura, 2019), 239, 301-302. Riho Altnurmes e-pasts V. Tēraudkalnam 2020. gada 6. martā.

Maikla Bordo e-pasts Valdim Tēraudkalnam 2020. gada 3. martā. Sk. arī Michael Bourdeaux, One Word of Truth: The Cold War Memoir of Michael Bourdeaux and Keston College (London: Darton, Longman and Todd Ltd., 2019), 52.

129 Dž. Satersveits - Anglijas baznīcas Ārlietu padomes generālsekretārs (1955-1970).

130 Confidential report, 14.08.1963., Lambeth Palace Library, CFR LRC 95/1, Latvia: Contacts: Archbishop Turs, 10.01.1955.-20.03.1973., 91 (sastādītājs nav norādīts, taču uz Satersveitu norāda iniciālıai JRS). Baznīcas virsvaldes sēdē 1962. gada 15. novembrī G. Tūrs ziņoja, ka pie viņa ieradies J. Vējš sakarā ar studiju beigšanu Oksfordā. Tā kā tur J. Vējš guvis tikai teorētiskas zināšanas, arhibīskaps noteicis viņam viena gada praksi Teolog̣isko kursu docenta mācītāja Artura Silı̧̧⿻s vadībā, kā arī pie citiem pasniedzējiem pēc vajadzības (LELB baznīcas virsvaldes plenārsēžu protokoli (27.01.1960.-17.10.1989.), LELB arhīvs, 1-3-42, Protokols Nr. 11, 15.11.1962., 46op-47). Pats J. Vējš stāsta, ka pēc atbraukšanas kontakti ar LELB notikuši nevis tieši, bet ar RKLP biroja starpniecību (Valda Tēraudkalna saruna ar Jāni Nameisi Vēju Jūrmalā 2020. gada 31. jūlijā). 
teiktā spriežot, uz "zinātniskā" ateisma grāmatu vākiem nebija ļauts likt reliǵisku simboliku vai baznīcu attēlus, uz monogrāfijas vāka ir no Anglijas līdzpaņemta albuma izgriezts britu parlamenta attēls. ${ }^{131}$ No mūsdienu viedokl l̦a raugoties, grāmata ir religijipētniecisks teksts, kas nebūt nav veidots vulgāra ateisma tradīcijā. Tajā ir daudz informācijas par Anglijas baznīcu, aplūkoti arī jaunākie strāvojumi tajā. Tolaik kontraversālā bīskapa Džona Robinsona (Robinson) teologija analizēta saistībā ar citu 20. gadsimta teologu - Paula Tiliha (Tillich), Dītriha Bonhēfera (Bonhoeffer) un Rūdolfa Bultmana (Bultmann) uzskatiem. ${ }^{132}$ Grāmatā aplūkota arī cita tā laika teoloǵiskā radikāla Džona Hika (Hick) teoloǵija. ${ }^{133}$ Lasītājs uzzina arī par filozofu Herbertu Markūzi (Marcuse), kas atškiıirībā no ortodoksālā marksisma uzskatīja, ka strādniecība mūsdienās vairs nav revolucionāru pārmaiņu instruments. ${ }^{134}$

Sākotnēji iecere bija, ka teolog̣iju Lielbritānijā varēs studēt vēl arī citi Latvijas pārstāvji - Dž. Fišers 1961. gadā rakstīja G. Tūram, ka priecājas, ka J. Vējam tik labi veicas ar studijām, un ka cer, ka pēc laika kādā no koledžām varēs studēt vēl kāds students. ${ }^{135}$ 1962. gadā G. Tūrs rakstīja RKLP Maskavā, ka pēc J. Vēja LELB vēlētos sūtīt uz Lielbritāniju Leonu Gabriēlu Taivanu, mācītāja L. Taivāna dēlu, "kas zina anglı valodu un vēlas studēt teoloǵiju”136. Par to RKLP pilnvarotais sniedza lakonisku kancelejisku atzinumu - "republikāniskās organizācijas iebilst pret Leona Taivana sūtǐšanu uz mācībām Lielbritānijā"137. Arī pats Tūrs vairs nebija tik optimistisks par to, ka viņa diplomātijas spējas var palīdzēt baznīcai izdzīvot - Dž. Satersveits 1963. gadā rakstīja, ka PLF asamblejas laikā ilgi runājis ar G. Tūru (R. Mužikam tulkojot), kas bijis l̦oti nomākts par baznīcas situāciju Latvijā un atzinis, ka teoloǵiskai izglītībai nav nedz mācību telpu, nedz iespējas iespiest grāmatas. Par iespēju studēt Anglijā Dž. Satersveits teicis, ka to būtu grūti noorganizēt, jo baznīcas budžetu ietekmē pēckara grūtības. G. Tūrs arī atzinis, ka viñam nav šobrīd neviena kandidāta, uz ko R. Mužiks piebildis, ka G. Tūra rekomendācija vēl nenozīmē, ka valsts iestādes l̦aus braukt. ${ }^{138} 20$. gadsimta sešdesmitie gadi

131 Valda Tēraudkalna saruna ar Jāni Nameisi Vēju Jūrmalā 2020. gada 31. jūlijā.

132 Janis Veish, Anglikanstvo v proshlom i nastojaschem (Moskva: Nauka, 1976), 128-129.

133 Ibid., 132-133.

134 Ibid., 138.

135 M. Ramsey to G. Turs, Christmas 1961, Lambeth Palace Library, CFR LRC 95/1, Latvia: Contacts: Archbishop Turs, 10.01.1955.-20.03.1973., 74.

136 G. Tūra vēstule Religisisko kultu lietu padomei PSRS MP [krievu val.], 31.05.1962., LNA_LVA, 1448-1-157, 42.

137 RKLP pilnvarotā P. Liepas vēstule RKLP pie PSRS MP priekšsēdētājam Puzinam [krievu val.], 14.07.1962., 43.

138 Confidential report,14.08.1963., Lambeth Palace Library, CFR LRC 95/1, Latvia: Contacts: Archbishop Turs, 10.01.1955.-20.03.1973., 91. 
baznīcai bija smags laiks, jo pastiprinājās represijas - tika vajāti garīdznieki, atņemti dievnami.

Pareizticības faktors Latvijas luterāṇu un anglikāṇu attiecībās
Anglikāņu "Church Times" sniegtā informācija par padomju garīdznieku delegācijas vizīti 1955. gadā rāda, ka anglikānu vadības skatījumā galvenais akcents tika likts uz kontaktiem ar KPB. 1955. gada 15. jūlijā publicēts raksts "Krievu pareizticīgie garīdznieki Lambetā". Tajā minēts, ka delegācijas sastāvā ir luterāņi un baptisti, taču lielākā raksta daļa ir par sarunām ar metropolītu Pitirimu un viņa nodoto ielūgumu Kenterberijas arhibīskapam apmeklēt PSRS. Tāpat ziņots, ka Pitirims preses konferencē teicis, ka PSRS ir pilnīga reliǵijas brīvība un garīgie semināri ir pilni ar jauniem cilvēkiem, kuri grib kḷūt par garīdzniekiem. ${ }^{139}$

Abas baznīcas - gan LELB, gan Anglijas baznīca - izrādijja interesi par sakariem ar pareizticīgajiem, tikai to motīvi un rīcības brīvības pakāpe bija atšksirīga. LELB šãdi kontakti saistijās gan ar labām personiskām baznīcu vadītāju attiecībām Latvijā (Latvijas Pareizticīgās baznīcas (LPB) arhibīskaps Filarets Ziemassvētku laikā Kristus piedzimšanas katedrālē rīkoja Betlēmes vakarus - kopīgu mielastu, uz kuru aicināja G. Tūru), ${ }^{140}$ gan ar to, ka baznīcu starptautiskie kontakti PSRS nereti notika ar KPB kā valstī lielākās kristīgās konfesijas starpniecību. LELB dažādos veidos akcentēja attiecību ar KPB nozīmi. LELB izdotajā baznīcas kalendārā 1963. gadam ir informācija par patriarhu Aleksiju sakarā ar viņa 85 gadu jubileju. Tajā līdzās viṇa kā miera cīnītāja slavināšanai ir pieminēti patriarha ekumeniskie kontakti ar LELB. ${ }^{141}$ Abas konfesijas Latvijā neveidoja teoloǵisku dialogu, lai gan dal̦a mācītāju droši vien atcerējās, ka LPB un LELB kontaktus pirms Otrā pasaules kara, kuri gan lielākoties neizgāja ārpus pieklājības vizī̌su rāmja. T. Grīnbergs ziņojumā mācītāju konferencē 1940. gadā no citām konfesijām pieminēja vien̄̄gi pareizticīgos: "Attiecības ar pareizticīgajiem ir labas, ar pārējiem dažādas." ${ }^{142}$ 1937. gadā Oksfordā ekumeniskās kustības "Baznīca un dzīve" konferencē līdzās T. Grīnbergam un Latvijas vācu luterāņu bīskapam Pēterim Pēlhavam (Pölchau) piedalijās pareizticīgo virspriesteris Jānis Jansons. ${ }^{143} \mathrm{~J}$. Jansons savukārt draudzējās ar

139 “Russian Orthodox Churchmen at Lambeth”, Church Times CXXXVIII: 4823 (15.07.1955.), 1.

140 Jefrosinija (Galina Sedova), “Pareizticīgā Baznīca Latvijā no 1945. līdz 1988. gadam”, Latvijas Pareizticīgā Baznīca. 1988.-2008. gads (Rīga: Latvijas Pareizticīgās baznīcas sinode, 2009), 17.

141 "Maskavas un visas Krievzemes patriarhs Aleksijs", Ev. lut. baznīcas kalendārs 1963. gadam (Rīga: [b. i., b. g.]), 75.

142 R. Zariņš, "Mācītāju konference”, Svētdienas Rīts 27 (30.06.1940.), 216.

143 “Arkiibīskaps Grīnbergs aizbraucis uz Oksfordu”, Brīvā Zeme 154 (14.07.1937.), 10. J. Jansons no 1933. līdz 1953. gadam kalpoja Kristus piedzimšanas katedrālē, pēckara gados - arī draudzē 
Artūru R. Harisonu (Harrison), kas bija Rīgas anglikāņu draudzes mācītājs divdesmitajos un trīsdesmitajos gados. ${ }^{144} \mathrm{~A}$. R. Harisonam nebija sveša pareizticīgo situācija arī Krievijā, jo no 1923. gada sākuma viņš, kamēr bija iespējams, apmeklēja arī Maskavu un toreizējo L̦eņingradu, noturot dievkalpojumus britu diplomātisko pārstāvniecību telpās (baznīcu ēkas šajās pilsētās jau bija atņemtas). ${ }^{145}$ Zīmīgi, ka pēc viņa nāves 1936. gadā tieši J. Jansons par viņu pareizticīgo katedrālē noturēja aizlūgumu. ${ }^{146} \mathrm{~J}$. Jansons pirms tam, divdesmitajos gados, jūsmīgi rakstīja Džonam Albertam Duglasam (Douglas), ${ }^{147}$ "ja anglikāņu baznīcas dal̦a atzīst, ka Euharistija ir upuris, tad var teikt, ka vienotība jau ir panākta”. Viņš arī aicināja Londonā sasaukt anglikāṇu un pareizticīgo koncilu. ${ }^{148}$ LPB arhibīskaps Jānis Pommers gan bija piesardzīgāks - 1927. gadā viņš rakstijja: "Lai nonāktu pie vienprātīgas ticības apliecināšanas, mums ir jāiemācās cienīt un mīlēt vienam otru ilgas, pat l̦oti ilgas savstarpējas iepazî̌šnās [..] cel̦ā." ${ }^{149}$

lepriekš minētajiem baznīcu tuvināšanās faktoriem klāt nāca politiskie aspekti. Pirmkārt, aukstā kara apstākḷos gan Lielbritānija, gan PSRS izmantoja šajās valstīs lielāko konfesiju sakarus ar pareizticību saviem mērķiem. Anglikāņu labās attiecības ar pareizticīgo baznīcām britu valdība izmantoja, lai tās iesaistītu plānotajā Rietumvalstu antikomunistiskajā aliansē. Jorkas arhibīskaps K. Garbits kalpoja par starpnieku, lai 1947. gadā ceļojuma laikā uz Balkānu regiona pareizticīgo baznīcām pildītu Lielbritānijas bijušā vēstnieka ASV lorda Edvarda Halifaksa (Halifax) uzticēto misiju, kuru rosināja ASV prezidents Harijs Trumens, kas uzskatijja, ka alianse būtu stiprāka, ja to atbalstītu baznīcas. ${ }^{150}$ Tāpat kā Lielbritānija, arī padomju vara izmantoja baznīcu savu ārpolitisko interešu îstenošanai, tikai tas notika radikāli citā kontekstā bez iespējām baznīcām

Bolderājā. Ar luterāņiem viṇa ceḷi trīsdesmitajos krustojās arī LU Teoloǵijas fakultātē, kuras Pareizticīgo nodal̦ā viņš pasniedza. Par J. Jansonu tuvāk sk. Mihail Tjurin, "Protoijerei loan Janson: Boljee poluveka na sluzhbe cerkvi Hristovoi”, Dobroje Slovo 5 (2020), 14-16.

144 Irīna Veisbārde, “Mans vectēvs Jānis Jansons...", Rīgas Balss 114/115 (19.05.1989.), 8.

145 Herbert Bury, Russia from Within: Personal Experiences of Many Years, and Especially since 1923 (London: The Churchman Publishing, [b. g.]), 15. https://archive.org/details/in.ernet. dli.2015.227015/page/n1/mode/2up?q=Harrison

146 “Rīgā miris anglikāņu baznīcas kapelāns”, Jaunākās Zingas 45 (24.02.1936.), 7.

147 Dž. Duglass - anglikāṇu garīdznieks, kuram bija būtiska loma Anglijas baznīcas dialogā ar pareizticīgajiem, Anglijas baznīcas Ārlietu padomes generālsekretārs līdz 1945. gadam. Ārlietu padomi izveidoja Kenterberijas arhibīskaps 1932. gadā.

148 John Jansons, Letter to J. A. Douglas (in Russian), 11.11.1925., J. A. Douglas Papers, Vol. 60, Lambath Palace Library, 61.

149 Jānis Pommers, "Anglikāņu bīskapu gaidot”, Rīgas un visas Latvijas arhibīskaps Jānis (Pommers), 1. sēj. Svētrunas, raksti un uzstāšanās, sast. Jānis Kalniņš (Rīga: Labvēsts, 1993), 70.

150 Dianne Kirby, "Divinely Sanctioned: The Anglo-American Cold War Alliance and the Defence of Western Civilization and Christianity, 1945-48", Journal of Contemporary History 35:3 (2000), 394. 
diskutēt par savu iesaisti. Tūlīt pēc kara sākās KPB delegāciju braucieni uz ārzemēm laikā no 1945. līdz 1946. gadam uz Franciju, Lielbritāniju, Austriju, Somiju, Ķīnu un citām valstīm brauca 17 delegācijas, kopā 52 cilvēki. Pirmo reizi KPB vēsturē Maskavas patriarhs (tobrīd Aleksijs) apmeklēja Svēto zemi. ${ }^{151}$ Šajos kontaktos padomju politiskās intereses savijās ar KPB vēlmi palielināt savu ietekmi. 1946. gadā Aleksijs rakstīja G. Karpovam, tā kā Konstantinopoles patriarhs ir zaudējis autoritāti, jāpanāk, lai pie "mātes-baznīcas" atgriežas Somijas, Polijas u. c. pareizticīgo baznīcas. ${ }^{152}$ 1948. gadā sakarā ar KPB autekefālijas 500 gadu jubileju Maskavā notika starptautiska konference, kas bija daļa no padomju ārpolitiskā plāna veidot KPB par vadošo pareizticīgo baznīcu un par nozīmīgu starptautisku aktoru kristietībā. Tādējādi PSRS cerēja mazināt tai naidīgā Vatikāna ietekmi. Krievu pareizticīgās baznīcas lietu padomes (KPBLP) pie PSRS Ministru padomes priekšsēdētājs Georgijs Karpovs informēja ārlietu ministra vietnieku Andreju Višinski, ka plānotās starptautiskās pareizticīgo konferences mērksis bija "nosodīt papisma antikristīgo un antidemokrātisko būtību un noraidīt pareizticīgo baznīcu dalību ekumeniskajā kustībā"153. PSRS ārpolitikas stratēgei, iespējams, cerēja arī uz daudzu Rietumu protestantu antikatolisko noskaņojumu - Kenterberijas arhibīskaps Dž. Fišers sauca situāciju Romas katol̦u baznīcā par "eklesiālu aparteīdu"154. Taču tas gan nenozīmēja simpātijas padomju sistēmai - Dž. Fišers rakstīja par PSRS un Vatikāna konfliktu kā "divu būtībā un metodēs totalitāru sistēmu sadursmi"155.

Otrkārt, padomju vara izmantoja KPB, lai ietekmētu citās baznīcās notiekošo. Piemēram, RKLP pilnvarotais ziņojumā par Vācijas Evaņgēliskās baznīcas pārstāvju vizīti,

151 Mihail Odincov, Russkaja pravoslavnaja cerkovj nakanune $i$ v epohu stalinskovo socializma (Moskva: ROSSPEN, 2014), 349.

152 Mihail V. Shkarovskij, Konstantinopolskaja i Russkaja cerkvi v period velikih potrjasenij (1910-ije 1950-ije godi) (Moskva: Poznanije, 2019), 135.

153 Daniela Kalkandjieva, The Russian Orthodox Church, 1917-1948: From Decline to Resurrection (London, New York: Routledge, 2015), 329. Konferences rezultāti bija niecīgi, tāpēc Staļins 1948. gada oktobrī atcēla iepriekš pieņemto lēmumu par 18 baznīcu un 10 lūgšanu namu atdošanu draudzēm. Atsākās represijas pret ticīgajiem, lai arī ne tik masveidīgas kā iepriekš. 1949. gada maijā aizvien pieaugošā kampaņa pret reliǵiju tika apturēta, jo tolaik bija tapis jauns plāns, kā religiskās organizācijas izmantot padomju valsts politiskajiem mērḳiem - tā bija PSRS inspirētā miera cīnītāju kustība. Aleksei Beglov, "Mezdunarodnaja dejatelnostj Russkoi Pravoslavnoi Cerkvi v period "novova kursa" v gosudarvstvenno-cerkovnih otnoshenijah. Osnovnije etapi i krizisnije jacvlenija”, Konturi globalnih transformacij: politika, ekonomika, pravo 11:4 (2018), 117.

154 "Archbishop Sounds a Note of 'Honest and Godly Partnership'”, Church Times CXXXVIII: 4822 (08.07.1955.), 1.

155 Dianne Kirby, "Harry S. Truman's International Religious Anti- Communist Front, the Archbishop of Canterbury and the 1948 Inaugural Assembly of the World Council of Churches", Contemporary British History 15:4 (2001), 47. 
kuras laikā G. Tūrs esot centies iesaistît viesu uzņemšanā pēc iespējas lielāku cilvēku skaitu, arī tādus, "kuri pazīstami ar "reakcionāriem uzskatiem"” (nosaukti mācītāji Haralds Kalniņš un Leons Taivāns), kā arī vēlējies viesiem parādīt pēc iespējas lielāku baznīcu skaitu, raksta, ka viña un LPB arhibīskapa Filareta sarunu ar G. Tūru rezultātā esot izdevies šīs aktivitātes mazināt. ${ }^{156}$ Trağiski, ka arī pats Filarets bija represēts - trīsdesmitajos un četrdesmitajos gados viņš tiesāts par kontrrevolucionāru darbību un izsūtīts uz ziemel̦iem. Viņa personīgajā lietā KPBLP Latvijas PSR pilnvarotais Aleksandrs Saharovs rakstija, ka Filaretam ir aizvainojums pret padomju varu, lai gan ārēji viņ̌ izrāda patriotismu. ${ }^{157}$ Šis ir viens no daudzajiem padomju vēstures piemēriem, kas rāda, ka kolaboracionisms un varas upuris nav vienmēr nesavienojami pretstati, bet nereti sadzìvo kopā.

Citreiz valdība klaji sagrozija notiekošo - sakarā ar plānoto Reformātu baznīcas atņemšanu varasiestādes LELB bija teikušas, ka "tā kā pareizticīgo baznīca nododot Valdībai [oriğināltekstā lielais sākuma burts - V. T.] savu katedrāli, valdība izteikusi ierosinājumu, lai arī ev. lut. baznīca izrādītu tai pretimnākšanu un nodotu vienu no savām baznīcu ēkām valsts arhīva vajadzībā, kā piemērotāko šim nolūkam atzīstot ReformātuBrālu draudzes baznīcu Rīgā”"158. Tas par spīti tam, ka LPB centās aizkavēt katedrāles atņemšanu.

Tuvināšanās meklējumi starp pareizticīgajiem un anglikāņiem bija ne tikai politiski, bet arī teologiiski. Tie pastāvēja jau ilgi pirms šajā rakstā aplūkotā laika posma - no 17. gadsimta, taču kļuva intensīvāki 19. gadsimtā līdz ar Oksfordas kustības (anglokatolıu) attīstību. Tas bija vērojams arī Latvijas teritorijā - kad 1900. gadā anglikāṇu Ziemel̦- un Centrāleiropas bīskaps Tomass Vilkinsons (Wilkinson) uzturējās Rīgā sakarā ar konfirmāciju, viņš apmeklēja arī dievkalpojumu pareizticīgo katedrālē, kur kā goda viesim viņam tika ierādīta vieta altāra tuvumā. ${ }^{159}$ 1906. gadā Anglijā tika dibināta Anglikāņu un Austrumu pareizticīgo baznīcu savienība (Anglican and Eastern Orthodox Churches Union), kuras mērḳis bija dialoga veicināšana starp abām konfesijām. Par vienu no tās prezidentiem kḷuva Latvijas teritorijā kalpojošais pareizticīgo arhibīskaps

156 KPBLP pilnvarotā A. Saharova un RKLP pilnvarotā J. Restberga ziņojums RKLP priekšsēdētājam I. Poḷanskim par Vācijas Evaņgéliskās baznīcas darbinieku delegācijas Rīgas apmeklējumu 1955. gada 2.-3. septembrī [krievu val.], 06.09.1955., 1448-1-254, 115.

157 Gaļina Sedova (Jefrosinija), Rizskaja jeparhija 1944-1964. Iz istorii pravoslavija (Daugavpils: Daugavpils Universitātes Akadēmiskais apgāds "Saule", 2020), 108-109.

158 Latvijas PSR Ev. lut. baznīcas virsvaldes plenārsēžu protokoli (27.01.1960.-17.10.1989.), LELB arhīvs, 1-3-42, Protokols Nr. 4, 25.01.1961., 9op.

"Riga", The Anglican Church Magazine CLXIV (1900), 118-119. 
Agafangels. ${ }^{160}$ Šim tuvināšanās procesam bija cieša saistība ar politiku - Krievijā viesojušos britu delegāciju, kuras sastāvā bija četri anglikāṇu bīskapi, pieņēma imperators Nikolajs II. Preses pārskatos uzskaitītas varas un prestiža izpausmes - vilciena stacijā imperatora uzgaidāmajā telpā Sanktpēterburgā delegāciju sagaidīja augstākie ierēdņi, ieskaitot galvaspilsētas mēru, vēlāk dievkalpojumā Kazaņas katedrālē bīskapi sēdēja pēc cara rīkojuma uz īpaša paklāja noliktos krēslos. ${ }^{161}$ Bīskaps Herberts Barijs (Bury) cel̦ojuma pa Krieviju piezīmēs neiztika bez politiskiem komplimentiem par abu impēriju brālīgajām saitēm. ${ }^{162}$

Ekumeniski noskaņotās aprindās plašu rezonansi izraisijja Konstantinopoles patriarhāta 1920. gada janvāra enciklika - aicinājums uz kristiešu vienotību. Tajā baznīcas un teologiijas mācību iestādes aicinātas veidot ciešas attiecības, kā arī rosināts kristīgajām konfesijām padzilıināti pētīt doktrinālās atšķirības, savstarpēji respektēt dažādās tradīcijas, l̦aut viena otrai izmantot dievnamus un kapsētas bērēm, atrisināt jautājumus, kas saistīti ar atšḳirīgām konfesijām piederošu partneru laulībām. Patriarhāts aicināja baznīcas veidot Tautu savienībai līdzīgu līgu - tā bija iecere, kas vēlāk īstenojās Pasaules baznīcu padomes izveidēe. ${ }^{163}$ Šo gadījumu tomēr nevajadzētu skatīt atrauti no politiskā konteksta - Konstantinopoles patriarhāts ar Rietumu baznīcu starpniecību meklēja politisku atbalstu pēc Osmaņu impērijas sabrukuma, kad pastāvēja bažas, ka turku republikāņi liks patriarham atstāt Stambulu. Patriarhāta pārstāvji, kas 1920. gadā apmeklēja anglikāņu Lambetas konferenci, izmantoja vizīti, lai gūtu ietekmīgu britu amatpersonu labvēlību. ${ }^{164}$ Tas neietekmēja KPB, kurai kā autokefālai baznīcai nebija saistoši Konstantinopoles patriarhāta lēmumi un kura atradās pilnīgi citā politiskā situācijā.

Anglijas baznīcas un KPB kontakti atjaunojās Otrā pasaules kara laikā. Tā kā līdzās KPB jurisdikcijā esošām draudzēm Rietumeiropā pastāvēja gan KPBĀ pakḷautas krievu pareizticīgo draudzes, gan tādas, kas piederēja Rietumeiropas ekzarhātam (Konstantinopoles patriarhāts), Anglijas baznīcai bija jāizdara izvēle. To kara laikā ietekmēja fakts, ka Lielbritānija un PSRS bija sabiedrotās. Kanoniķis P. E. T. Vidringtons (Widdrington)

160 Agafangels no 1897. gada bija Rīgas un Mītavas (Jelgavas) bīskaps, no 1904. gada - arhibīskaps. 1910. gadā viņu pārcēla uz Vil̦nu. "Metropolīts Agafangels", http://www.russkije.lv/lv/lib/read/ agafangel-arch-bishop-of-riga-and-mitava.html?source=hierarchs (skatīts 04.05.2020.)

161 "English Churchmen Visit Russia”, Living Church 46 (17.02.1912), 532. Šĩ vizīte tika atspogulota arī Latvijas presē - "Anglu viesi Krievijā", Jaunās Latviešu Avīzes 5 (17.01.1912.), 2.

162 Herbert Bury, Russian Life Today (London: Mowbray \& Co, 1915), 114. Grāmatas e-versiju sk. https://archive.org/details/russianlifetoday00bury/page/114/mode/2up (skatīts 07.05.2020.)

163 "Encyclical of the Ecumenical Patriarchate, 1920. Unto the Churches of Christ everywhere", The Orthodox Church in the Ecumenical Movement: Documents and Statements 1902-1975, ed. Constantin G. Patelos (Geneva: World Council of Churches, 1978), 40-43.

164 Bryn Geffert, "Anglican Orders and Orthodox Politics", The Journal of Ecclesiastical History 2 (2006), 273. 
1944. gadā H. Vadamsam pauda viedokli, ka Anglijas baznīcai jāpārtrauc atbalsts KPBĀ, un nepiekrita Dž. Duglasam, kas domāja, ka KPBĀ politiskās aktivitātes iespējams nodalīt no reliǵiskajām. ${ }^{165} \mathrm{KPBA} \overline{\mathrm{A}}$ neskaidrais kanoniskais statuss, hitlerisko Vāciju atbalstošs noskaņojums dal̦ā tās hierarhu un tās antiekumeniskā nostāja veicināja to, ka KPB likās daudz pievilcīgāka sadarbības partnere. ${ }^{166}$ Negribot šāda anglikāñu izvēle atbilda padomju ārpolitikai, kas ar KPB starpniecību centās diskreditēt KPBĀ kā "balto" emigrantu organizāciju. ${ }^{167}$

lepriekš sacītais gan nenozīmē, ka 19. un 20. gadsimtā visiem pareizticīgajiem un anglikāņiem šāds dialogs bija pieņemams. Ja anglokatol̦iem bija interese izveidot ciešāku sadraudzību ar Romas katol̦iem, pareizticīgajiem un veckatolıiem, tad anglikāņu evaņgelikāliem - ar nekonformistiem (baptistiem, prezbiteriāņiem un citiem). Pa vidu bija tie anglikāņi, kuri uzskatīja, ka vienoties var gan ar vieniem, gan otriem. Kenets Makmorans (Macmorran) aicināja puses uzklausīt vienai otru un, cik iespējams, vienoties. Viņš arī pragmatiski norādīja, ka aicinājums uz kristiešu vienotību primāri nāk no misijas laukiem. ${ }^{168}$ Evañgelikālsi bija skeptiski - šajā ziñā tipiska ir 19. gadsimtā sarakstītā Džozefa Brauna (Brown) polemiskā grāmata "Turcijas, Grieķijas un Krievijas kristiešu elkdievība, māñticība un korupcija”. Tās autors raksta, ka ir kḷūdaini pievērst pārāk lielu uzmanību pareizticīgo doktrīnām, jo pat garīdznieki un vēl jo mazāk laji tās nezina. ${ }^{169}$ Tipiska viktoriāņu laika protestantismam ir autora sniegtā Atona mūku kopienu kritika - mūku praktizētie rituāli būtu par sarežǧītu pat Japānas vai Ķīnas

165 P. E. T. Widdrington to H. Waddams, 12.06.1944., Lambeth Palace Library, CFR G 9/1, Communism: Russia, 1941-1963, 92.

166 1938. gadā, pēc tam kad Vācija bija atbalstījusi 19 pareizticīgo baznīcu remontu, KPBĀ metropolīts Antonijs nosūtīja pateicību Hitleram. KPBĀ kapelāni kalpoja Krievu atbrīvošanas armijā. KPBĀ antiekumenisms kulminēja 1983. gadā baznīcas lāsta (anatēmas) uzlikšanā ekumeniskajai kustībai. Arkadij Makoveckij, Belaja cerkovj vdali ot ateistichiskovo terora: istorija Ruskoi pravoslavnoi zarubeznoi cerkvi (Sanktpeterburg: Piter, 2009), 133-134, 195. Kas attiecas uz atbalstu nacistu režīmam, tad šādus kompromisus ar vācu okupācijas varu gan piel̦āva arī okupētajās teritorijās esošās KPB pakḷautībā palikušās pareizticīgo draudzes. Pateicības telegrammu Hitleram 1942. gadā nosūtīja Baltijas bīskapi, ieskaitot metropolītu Sergiju, kuru 1940. gada beigās KPB atsūtīja pārņemt baznīcas Igaunijā un Latvijā. "Pareizticīgo bīskapu rezolūcija", Kurzemes Vārds 175 (01.08.1942.), 2.

167 Sk., piemēram, Aleksija 1945. gada vēstījumu KPBĀ, kurā patriarhs izmantoja emocionāli iedarbīgus argumentus par nācijas un dzimtenes nodevību. "Obraschenije patriarha Moskovskovo i vseja Rusi Aleksija k arhipastirjam i kliru tak nazivajemoi Karlovackoi orinetacii”, Zhurnal Moskovskoi Patriarhii 9 (1945), 9-12. http://www.jmp.ru/ya43.php?ys=45\&my=09\&rm=0FC4\& $\mathrm{sr}=450903$ (skatīts 01.08.2020.)

168 Kenneth M. Macmorran, Reunion and the Lambeth Conference: A Charge (London: A. R. Mowbray, 1930), 9.

169 Joseph Brown, The Idolatry, Superstition and Corruption of the Christians of Turkey, Greece and Russia (London: Edward Stanford, 1877), 8. 
imperatoram, "vinu garlaicīgo monotono dzīvi nekad neiepriecina vai neatvieglo sievietes klātbūtne"170. Šajā frāzē atspoguḷojas ne tikai tā laika protestantismam raksturīgā ǵimenes dzīves akcentēšana, bet arī patriarhālisms, jo sieviete šajā modelī domāta vĩrieša iepriecinājumam. Ar pārākuma apziņu autors pretstata anglikāņu garīdzniekus ("izglītoti, labestīgi kristīgi džentlmeņi”) nabadzīgiem, netīriem pareizticīgo garīdzniekiem - zemniekiem. ${ }^{171}$ 20. gadsimta argumenti pret tuvināšanos pareizticīgajiem bija mazāk polemiski un emocionāli, taču atšḳirīgās pamatnostādnes saglabājās. ${ }^{172}$ lebildumi bija arī pareizticīgajiem, kuriem nebija pieņemams anglikāņu pragmatisms, kas pie!̧āva dažādību doktrinālos un liturǵiskos jautājumos. Kā, rakstija Dž. Duglass, "kad viṇi starp mums redzēja to, ko viņi sauca par "augsto" un "zemo" baznīcu, tas viņiem nebija saprotams" "173. Pareizticīgo-anglikāṇu teologiskajā dialogā 1956. gadā Maskavā pareizticīgie kritizēja anglikāņu pausto viedokli, ka dogmas var tikt formulētas arī dziesmās un lūgšanās. Pareizticīgo jautājums bija konkrēts - vai anglikāņi atzīst septiņu ekumenisko koncilu lēmumus. ${ }^{174}$ Tāpat pareizticīgajiem bija būtiski noskaidrot anglikāņu nostāju filioque jautājumā. Anglikāņu atbildes uz šādiem jautājumiem bija izvairīgas. Vēl arī jāngem vērā, ka Rietumu protestantu priekšstati par krievu pareizticību bieži veidojās ekumenismam simpatizējošu emigrācijā dzīvojošu krievu teologu (piem., Sergeja Bulgakova) darbu ietekmē, taču vingu viedoklis KPB bija margināls. ${ }^{175}$

170 Joseph Brown, The Idolatry, Superstition and Corruption of the Christians of Turkey, Greece and Russia (London: Edward Stanford, 1877), 11.

171 Ibid., 48.

172 Arī mūsdienās evangégelikālı kā labas prakses paraugu min 1931. gada Bonnas vienošanos starp Anglijas baznīcu un veckatol̦iem, kas runā par vienību kristietības pamatmācībā un atzīst, ka interkomūnija neparedz abu pušu doktrinālo un liturǵisko atškirīibu savstarpēju pieņemšanu. Skat. ievērojamu anglikāṇu evaņgéelikālu atklāto vēstuli par attiecībām ar Romas katoḷu, pareizticīgo, veckatoḷu un Austrumu orientālajām baznīcām (1977. g.): R. T. Beckwith, G. E. Duffield, J. I. Packer, Across the Divide (Basingstoke: Lyttelton Press, 1977), 8.

173 "The Lambeth Conference and the Eastern Churches", Church Times LXXXIV:3015 (05.11.1920.), 453.

174 "Minutes of Theological Discussions", Anglo-Russian Theological Conference, Moscow, July, 1956, ed. H. M. Waddams (London: The Faith Press, 1958), 83.

175 Šajā rakstā iepriekš minētajā 1948. gada konferencē Maskavā Krievijas un Bulgārijas pareizticīgo baznīcu mūsdienās kanonizētais arhibīskaps Serafims, kas tolaik bija krievu pareizticīgo draudžu administrators Bulgārijā, sauca S. Bulgakovu par herētiķi. "The Meetings of the Commission on the Question of "The Oecumenical Movement and the Orthodox Church"”, Major Portions of the Proceedings of the Conference of the Heads of the Autocephalous Orthodox Churches in Conncetion with the Celebration of 500 Years of Autocephalicity of the Russian Orthodox Church (Paris: YMCA Press, 1952), 221. 

zācijas centās veidot starptautiskos kontaktus, pielāgojoties ikdienas dzīves reālijām. Baznīcas izmantoja uz padomju ārpolitikas stratēgisko mērḳu apmierināšanu vērsto "parādes" ekumenismu, lai gūtu papildu labumus - iespējas studēt teologiju ārzemēs, iesaistīties starptautiskās kristīgās organizācijās, veicināt apmaiñas vizītes u. c. Tas nebija iespējams bez kompromisiem, bez sadarbības ar valsts iestādēm. Kolaboracionisms vēl aizvien ir jūtīga tēma Latvijas sabiedrībā, un ir tendence to vai nu noklusēt, vai "piekārt" vērtībspriedumus, taču laikā, kad cilvēkiem nebija nekāda cerība uz krasām pārmaiñām, viṇi pielāgojās apstākḷiem, cenošoties dzīvot pēc iespējas pilnvērtīgāku dzīvi, tāpēc melnbalts skatījums kropḷo padomju laika dzīves analīzi. ${ }^{176}$ Tikpat problemātiski ir valsts varas mēǵinājumi leǵitimēt vienu "pareizo" pagātnes versiju. ${ }^{177}$ Latvijā lustrācija diemžēl nav notikusi un šobrīd ir nokavēta, politiskajai elitei gadu desmitiem nespējot izlemt par VDK dokumentu nodošanu atklātībai un kavējot šo procesu.

Padomju varasiestādes nespēja kontrolēt visu, tāpēc šie kontakti neizbēgami pavēra ceḷu valsts iestāžu negribētai informācijas apmaiņai un neformālām attiecībām. Līdzīgi tas bija ar citiem destaļinizācijas apstākḷıs īstenotiem projektiem, piemēram, Vispasaules jaunatnes festivālu Maskavā 1957. gadā. Lai gan tāpat kā baznīcu attiecības tas bija iecerēts kā padomju propagandas pasākums, nebija iespējams pilnībā kontrolēt PSRS jauniešu kontaktus ar ārzemniekiem par spīti piesardzības pasākumiem.

Rietumu partneri saskārās ar diasporas baznīcu kritisko attieksmi pret oficiāliem Rietumu-Austrumu bloka valstu baznīcu kontaktiem, tomēr šis viedoklis neizrādījās noteicošais. Diasporas attieksme bija pretrunīga, jo līdzās oficiālu kontaktu noliegumam tā uzturēja privātus sakarus ar baznīcām okupētajās zemēs (iesk. baznīcu vadītājus), un izteikumiem publiskajā telpā nereti bija vairāk performatīva loma. Anglijas baznīcai līdzās vēlmei atbalstīt ticīgos PSRS bija arī mērḳis tuvināties pareizticīgo baznīcām un turpināt pirms Otrā pasaules kara sākto dialogu ar Skandināvijas un Baltijas luterāṇu

176 Zinātniskajā diskursā neeksistē viena kolaboracionisma definīcija. Tiesu sistēmas mēgeinājumi legitimēt vienu no tām tāpēc uzskatāmi par apdraudējumu vārda brīvībai. Sk., piemēram, Ogres rajona tiesas spriedumu vēsturnieka Gata Liepiņa lietā (2018. g.), kurā tiesnesis Arnis Naglis izmantojis padomju laika vārdnīcā un Vikipēdijā atrodamus skaidrojumus. Turklāt izmantota Vikipēdijas latviskā, nevis angliskā versija, kurā ir plašāks kolaboracionisma skaidrojumu un definīciju klāsts. "Spriedums", https://ir.lv/wp-content/uploads/2018/03/Spriedums-Laizani1.pdf (skatīts 25.07.2020.)

177 Negatīvs piemērs tam ir Polijas centieni kriminalizēt tādus holokausta skaidrojumus, kas parāda poḷu līdzdalību ebreju iznīcināšanā. Starptautiskā spiediena rezultātā likums 2018. gadā gan tika mīkstināts. Marc Santora, "Poland's Holocaust Law Weakened After 'Storm and Consternation'”, https://www.nytimes.com/2018/06/27/world/europe/poland-holocaust-law.html (skatīts 25.07.2020.) 
baznīcām. Tāpat kā mūsdienās anglikāņu pozīcija šajā ekumeniskajā procesā bieži bija pragmatiska un atkarīga no tā, kādas anglikānisma tradīcijas pārstāvji sarunās piedalījās.

\title{
SUMMARY
}

\author{
A time of hope: ELCL contacts with the Church of \\ England during the work of Archbishop Gustavs Tūrs \\ (1946-1968)
}

The purpose of this article is to analyse relationships of the Evangelical Lutheran Church of Latvia (ELCL) with the Church of England during Gustavs Türs' time as archbishop. Special attention is given to his visit to U.K. in 1955 as a member of the delegation of Soviet clergy. These contacts are placed in various contexts - theological, socio-political, personal relationships. "Voices" from various sources are placed face to face and confronted with each other. The author has explored materials previously unused in scientific circulation in Latvia - the archive files stored at the Lambeth Palace Library (London).

Contacts between the two churches is a continuation of relationships maintained before the Second World War. Delegations of the Lutheran Churches in Estonia and in Latvia had meetings with representatives of the Church of England in 1936 and in 1938. These negotiations resulted in agreement on intercommunion that because of the war was never ratified but respected by the involved parties.

The first years after Stalin's death was a "thaw", when repression and censorship in the Soviet Union was relaxed. The renewed interest of Soviet leadership in using religious organizations for Soviet foreign politics was used by churches to further their own aims.

They tried to reap additional benefits from the Soviet-inspired "parade ecumenism" - theological studies abroad, exchange visits, etc. However, it was not achieved without compromises. Here pops up a theme of collaborationism, which still is sensitive in post-Soviet countries. It may seem easy to evaluate this phenomenon from today's perspective, whereas for people having no hope that situation would change in their lifetime, adjusting to the political realities was the only option they had. Of course, the question remains what kind of concessions they made to the Soviet system.

Contacts between the churches in U.K. and Latvia helped to exchange information; they paved the way to membership in international organizations like the World Lutheran Federation. For Anglicans, the main emphasis during the visit of the delegation of Soviet clergy in 1955 was on Orthodox-Anglican relationships. It is related to the fact that the High-Church movement at that time was at its zenith of influence in the Church of England. The attitude of the Latvian Lutheran Church in diaspora was negative, because it did not recognize ELCL as legitimate, nevertheless, this attitude was not consistent, because the leadership of diaspora church simultaneously tried to maintain personal contacts with the colleagues in Latvia. 